\title{
Regional-Scale Ozone Deposition to North-East Atlantic Waters
}

\author{
L. Coleman, S. Varghese, O. P. Tripathi, S. G. Jennings, and C. D. O'Dowd
}

School of Physics and Centre for Climate and Air Pollution Studies, National University of Ireland, Galway, Ireland

Correspondence should be addressed to L. Coleman, colin.odowd@nuigalway.ie

Received 15 February 2010; Revised 28 May 2010; Accepted 16 July 2010

Academic Editor: Elisabetta Vignati

Copyright $\odot 2010$ L. Coleman et al. This is an open access article distributed under the Creative Commons Attribution License, which permits unrestricted use, distribution, and reproduction in any medium, provided the original work is properly cited.

A regional climate model is used to evaluate dry deposition of ozone over the North East Atlantic. Results are presented for a deposition scheme accounting for turbulent and chemical enhancement of oceanic ozone deposition and a second non-chemical, parameterised gaseous dry deposition scheme. The first deposition scheme was constrained to account for sea-surface ozone-iodide reactions and the sensitivity of modelled ozone concentrations to oceanic iodide concentration was investigated. Simulations were also performed using nominal reaction rate derived from in-situ ozone deposition measurements and using a preliminary representation of organic chemistry. Results show insensitivity of ambient ozone concentrations modelled by the chemicalenhanced scheme to oceanic iodide concentrations, and iodide reactions alone cannot account for observed deposition velocities. Consequently, we suggest a missing chemical sink due to reactions of ozone with organic matter at the air-sea interface. Ozone loss rates are estimated to be in the range of $0.5-6 \mathrm{ppb}$ per day. A potentially significant ozone-driven flux of iodine to the atmosphere is

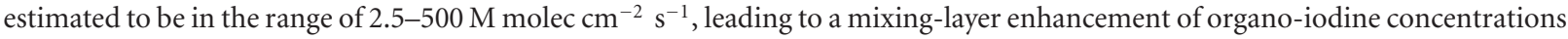
of $0.1-22.0 \mathrm{ppt}$, with an average increase in the N.E. Atlantic of around $4 \mathrm{ppt}$ per day.

\section{Introduction}

Ozone plays a key role in atmospheric chemistry, absorbing harmful UV rays in the stratosphere whilst simultaneously acting as a greenhouse gas (radiative forcing of tropospheric ozone is around $25 \%$ that of $\mathrm{CO}_{2}$ [1]), and acting as a harmful pollutant in the troposphere [2-4]. Influencing the oxidising capacity of the atmosphere as a powerful oxidising agent, it is the dominant precursor to the ubiquitous hydroxyl radical which acts as an atmospheric cleansing agent by determining the lifetime of important atmospheric trace gases. It is vital, therefore, that tropospheric ozone concentrations are realistically simulated in modelling both air pollution and chemistry-climate interactions.

600-1000 $\mathrm{Tg} \mathrm{O}_{3}$ year $^{-1}$ is removed from the troposphere via dry deposition [5]. The deposition of ozone to water surfaces is small compared to deposition to land [6]: typically, the rate of dry deposition of ozone to the continent is nearly six times faster than the dry deposition rate of ozone to the ocean [7]. However, considering $70 \%$ of the globe has ocean coverage, the loss of marine boundary layer ozone via oceanic dry deposition still represents a significant sink for the global ozone budget. Obtaining an accurate prediction of ozone flux to the sea is imperative not only in predicting ambient ozone concentrations, but also because of the biogeochemical consequences of ozone reactions in the sea surface.

For example, recent work $[8,9]$ has shown that ozonation of iodide in the sea surface can result in the formation of reactive organoiodine products that result in iodocarbon emissions from the sea surface. These iodocarbons photodissociate rapidly form iodine atoms which are known to catalytically destroy ozone [10], resulting in further reduction of marine boundary layer ozone levels. Also, ozonation of iodine atoms results in formation of iodine oxide (IO) radicals which have the potential to lead to new marine aerosol formation [11]. This newly discovered mechanism could have significant biogeochemical consequences, in terms of the feedback mechanism in halogen-mediated ozone destruction, the halogen source in coastal areas which 
could account for the hitherto unexplained elevated levels of IO observed at Cape Verde [12], and the subsequent formation of new particles which could influence the solar radiation budget.

There is still major uncertainty regarding the amount of ozone lost to the ocean by dry deposition [13]. The dry deposition of ozone to the ocean involves a number of complex processes: physical, chemical, and biological. Transport of ozone through the atmosphere depends on surface roughness, wind speed, and atmospheric turbulence; transport across the quasilaminar boundary layer is limited by the diffusivity of the gas in air, while the ocean-surface uptake of ozone depends on the water-side turbulence conditions, ozone solubility, and availability of reacting chemicals in the surface layer $[14,15]$. Up to now, these processes have been poorly understood and have not generally been considered in deposition schemes commonly applied in atmospheric chemistry models. The difficulty in the definition, and therefore the parameterisation of these processes is exacerbated by the scarcity of in situ measurements of ozone dry deposition velocities. Wesely and Hicks [16] found deposition velocities of ozone to the sea surface to vary between 0.01 and $0.05 \mathrm{~cm} \mathrm{~s}^{-1}$. However, the eddy correlation studies of Gallagher et al. [17] carried out in the North Sea indicate deposition velocities as high as $0.1 \mathrm{~cm} \mathrm{~s}^{-1}$.

The rate of gaseous dry deposition to a surface is parameterised by deposition velocity, $V_{d}\left(\mathrm{~cm} \mathrm{~s}^{-1}\right) . V_{d}$ is used to calculate the downward flux of ozone to the ocean, $F_{O 3}$ $=V_{d} C$ where $C$ denotes surface level gas concentration. $V_{d}$ is computed (in analogy with electrical transport) as the reciprocal of the sum of the resistances encountered by the gas on its journey to the surface sink. Using the standard resistance model to compute deposition velocity, resistances to gaseous deposition are atmospheric resistance, quasilaminar resistance and surface resistance [14].

The gaseous dry deposition scheme of Wesely [18] is widely applied in air quality, atmospheric chemistry, and chemistry climate models to represent gaseous dry depositional sinks. In its evaluation of deposition velocity, this scheme calculates explicitly only aerodynamic resistance and resistance to transfer across the quasilaminar surface layer. Surface resistance is calculated as a series of smaller resistances which are generally provided by look-up tables, with values differing according to land use type, species in question and season. In this system, derivation of surface resistance to deposition at water surfaces is neglected and surface resistance is set to a constant value of $2000 \mathrm{~m}^{-1} \mathrm{~s}$. The same surface resistance is applied to all water surfaces, irrespective of water body classification, climate, or meteorological conditions, thereby grossly simplifying the complex mechanisms involved in surface transfer. Surface resistance is the most significant parameter in the case of ozone deposition to the ocean [19] and in reality, surface resistance is greatly diminished by turbulence in the ocean surface and by the presence of ocean-depleting chemicals in the ocean surface - namely iodide [20,21], and organic matter [22], for example, chlorophyll [23] and DMS [5, 20]. Due to the highly reactive nature of ozone, these ocean surface reactions can have a very significant enhancing effect on oceanic ozone deposition and the chemical reactions between ozone and organic matter and chlorophyll have yet to be parameterised and constrained in dry deposition models.

Due to it's parameterisation of surface resistance, the dry deposition scheme of Wesely [18] underestimates deposition rate of ozone to the ocean at both high- and low-wind speeds compared to observations [20].

The advanced Fairall et al. [13] scheme described in Section 2.1 is an explicit parameterisation of ozone deposition to the ocean, allowing for enhanced ozone deposition due to ocean surface turbulence and ocean surface layer reactions.

The Fairall et al. scheme has recently been incorporated into a global model, with analysis, discussion on role of controlling parameters, and validation the parameterisation conducted by Ganzeveld et al. [5]. In this study, the parameterisation is scaled to include reactions of ozone with iodide, dimethyl sulfide (DMS), alkenes, and organic chemistry. The study finds the role of biogeochemistry to dominate in computation of deposition velocities in the tropical and subtropical regions whereas the turbulent forcing of ozone deposition dominated over biogeochemical factors in the mid to high latitudinal regions. Simulation results indicate a small sensitivity of marine boundary layer ozone concentrations to varying biogeochemical and turbulent conditions, despite the wide range of deposition rates simulated using the Fairall et al. [13] scheme which is scaled to include organic reactions. This occurs partly due to interaction of different factors affecting deposition velocity. For example, in tropical regions, the reducing effect of high water temperature values on ozone solubility in water counteracted higher chemical ozone transfer due to elevated iodide concentrations. As a result, applying enhanced iodide concentrations in coastal regions did not explain discrepancies between observed and simulated $V_{d O 3}$. Furthermore, the lack of sensitivity of simulated boundary layer ozone concentration to dry deposition velocity illustrates the role of compensating effects in climate models due to atmospheric transport and chemistry which maintain ozone concentrations within the marine boundary layer, despite the temporal and spatial variability in oceanic ozone uptake. The global model study also found the use of the advanced Fairall et al. [13] scheme in the model only slightly reduced $(\sim 6 \%)$ the total dry deposition flux of ozone to the ocean compared to simulations ran using the Wesely [18] scheme with constant surface-resistance. This shows that the Wesely [18] scheme is appropriate for modelling ozone deposition on a global scale for an annual period, but it is thought that due to the North East. Atlantic region being both organically active and prone to turbulent conditions, use of the chemically enhanced Fairall et al. [13] scheme on ozone concentrations in this area may be more significant due to regional-scale, short-term effects than indicated by findings of the global model study of Ganzeveld et al. [5]. Also, as the effect of temperature on molecular diffusivity is accounted for in this study, it is thought that the limiting effect of ozone water solubility on computed deposition velocities will be less pronounced than found in the global model study (see Section 2.2.3). Furthermore, in contrast 
with the global model simulations, in this study the effect of salinity on ozone solubility, diffusivity, and ozone-iodide reaction rates are included. Our analysis shows that effect of salinity on ozone-iodide reactions can enhance reaction rates by as much as $23 \%$ (Section 2.3.1). Including the effect of salinity on key parameters accounts for further variations between results the global model study and results of regional model simulations presented here.

For this study, the Fairall et al. [13] parameterisation has been adapted to account for enhanced deposition due to iodide-ozone reactions in the ocean-surface layer. Furthermore, a mechanistic scaling to account for marine organic chemistry using oceanic chlorophyll concentrations as a proxy for organic activity has been included in the scheme. The parameterisation is then incorporated into the regional climate model with tracer extensions (REMOTE) $[24,25]$ and the sensitivity of simulated ozone flux and ambient ozone concentrations to varying oceanic iodide concentrations and inclusion of organic chemistry is investigated.

\section{Methods}

2.1. Details of the Fairall et al. [13] Parameterisation of Oceanic Ozone Deposition. The ozone deposition parameterisation of Fairall et al. [13] calculates oceanic ozone dry deposition velocity by integration of the turbulentmolecular transport equation in the ocean, while accounting for increased deposition of ozone to the ocean due to sea surface turbulence and due to surface-level chemical reactions. The sea-surface turbulence is a function of wind speed, water density, and the buoyancy flux of water [26].

Chemical reactions are integrated into the scheme by way of reactivity time-scale term, $A_{\mathrm{oz}}\left(\mathrm{s}^{-1}\right)$ which characterises the time scale of a chemical reaction for ozone in the sea water. It is calculated as the product of the sea-surface concentration of the ozone reactant $\left(C_{i}\right)$ and a second order rate constant $\left(k_{i}\right)$ for the reaction in question

$$
A_{\text {ozone }}=\sum C_{i} k_{i} .
$$

Instead of using the three-resistance approach of Wesely [18], this parameterisation combines atmospheric and quasilaminar resistance into one resistance term which is calculated using the tropical ocean global atmosphere coupled ocean-atmosphere response experiment (TOGA-COARE) gas transfer model $[27,28]$. The bulk of the parameterisation serves the computation of the turbulence-dependent surface resistance with an added chemical enhancement term. The scheme has been modified to allow for variation of iodide reaction rates with temperature [29], variation of ozone diffusivity in water due to temperature [30] and salinity [31], and variation of ozone solubility with temperature [32].

\subsection{Sensitivity Analysis}

2.2.1. Turbulent/Nonturbulent Scheme. The Fairall et al. [13] scheme computes surface resistance by first solving the conservation equation for the case of negligible turbulence.
From this solution, the turbulent solution is calculated by considering a turbulent eddy diffusivity term obtained using surface-layer similarity scaling [27]. From the scheme, deposition velocities are effectively calculated for two cases: negligible turbulence and nonnegligible turbulence. Figure 1 depicts deposition velocities obtained from the turbulent and nonturbulent schemes as a function of reactivity for various wind speeds, displaying how the turbulent and nonturbulent schemes converge for very high water-side reactivity values. This convergence occurs due to destruction of ozone in the surface layer occurring so rapidly that ocean turbulence has no enhancing effect on deposition velocity. The magnitude of the effect of ocean surface turbulence on deposition velocity depends on the reactivity term. For high-wind speeds (conditions of significant ocean surface turbulence), the deposition velocity is less dependent on reactivity than in the nonturbulent case (lower wind speeds). This illustrates the dominance of turbulent forcing over the reactive sink at high-wind speed.

2.2.2. Sensitivity of Deposition Velocity to Reactivity Term. The deposition velocities predicted by the Fairall et al. [13] scheme following a simulation in REMOTE were plotted against their corresponding wind speeds for various reactivity values, in order to look at the sensitivity of deposition velocity to the reactivity time scale factor $\left(A_{\mathrm{oz}}\right)$, as shown in Figure 2. Deposition velocities computed by the Wesely [18] scheme were also plotted in Figure 2, for comparative purposes. A significant increase in deposition velocity from the Fairall et al. [13] scheme is observed in Figure 2 for wind speeds over $4 \mathrm{~m} \mathrm{~s}^{-1}$ for reactivities exceeding $1000 \mathrm{~s}^{-1}$. At lower reactivities, the Wesely [18] scheme predicts higher deposition velocities, especially at low-wind speeds.

The reactivity value needed in the Fairall et al. [13] parameterisation to match deposition velocities computed by the Wesely [18] scheme depends on the wind speed value. For low-wind speeds (under $4 \mathrm{~m} \mathrm{~s}^{-1}$ ), reactivity of $1000 \mathrm{~s}^{-1}$ yields similar deposition velocities to those predicted by Wesely [18]. For high-wind speeds (over $10 \mathrm{~m} \mathrm{~s}^{-1}$ ), waterside reactivity of $100 \mathrm{~s}^{-1}$ would yield deposition velocities in the same range as those predicted by Wesely [18]. Therefore, for deposition velocities exceeding those predicted by the nonchemical, nonturbulent Wesely [18] scheme, reactivity in the ocean should exceed $1000 \mathrm{~s}^{-1}$. At low reactivities, the Fairall et al. [13] parameterisation predicts a linear relationship between deposition velocity and wind speed, due to the dominance of the turbulent driven deposition over the chemical sink, as discussed in the previous section.

In their sensitivity analysis of the parameterisation, Fairall et al. [13] found that using the chemically enhanced turbulent deposition scheme, typical observed ozone deposition velocities of $0.05 \mathrm{~cm} \mathrm{~s}^{-1}$ would require a reactivity rate of $1000 \mathrm{~s}^{-1}$. This can be observed from Figure 2. Gallagher et al. [17] observed ozone deposition velocities to the ocean as high as $0.1 \mathrm{~cm} \mathrm{~s}^{-1}$ in the North Sea. Deposition velocities of this magnitude would require a reactivity rate of the order of $10^{4} \mathrm{~s}^{-1}$ using the Fairall et al. [13] scheme at low to moderate wind speeds. 


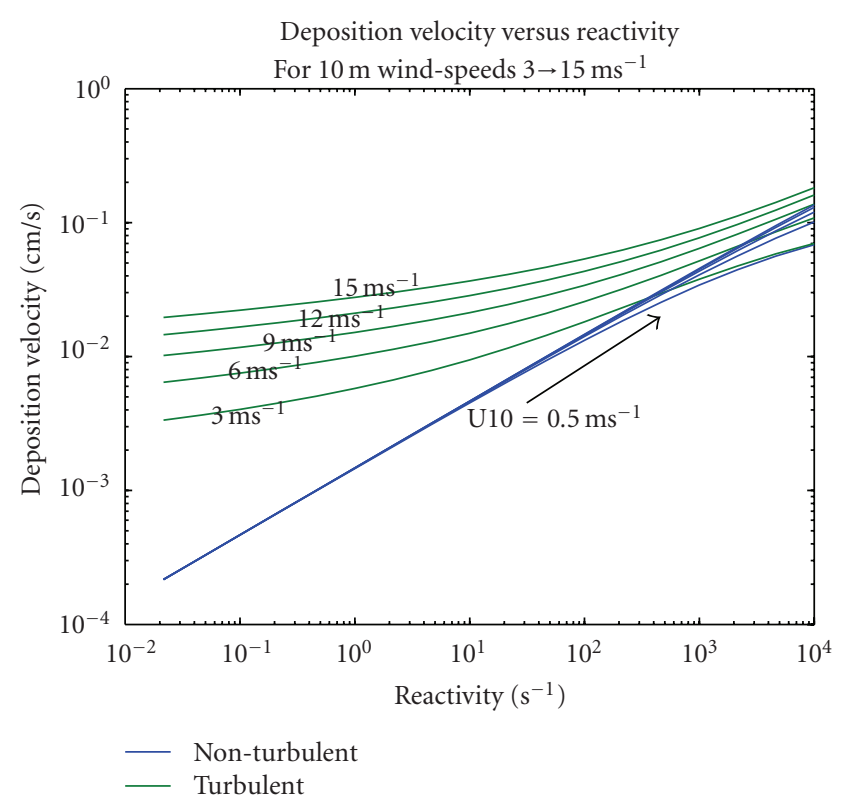

Figure 1: Comparison of deposition velocity as a function of reactivity for the nonturbulent and the turbulent Fairall et al. [13] scheme for differing $10 \mathrm{~m}$ wind-speeds (U10). Nonturbulent deposition velocity is obtained by solution of the basic ozone conservation equation, whereas the turbulent deposition velocity is obtained by solution of the conservation equation including a turbulent eddy diffusivity term that is obtained from surface-layer similarity scaling [27]. Note how both schemes converge for high reactivity values. This occurs because in incidences of very high oceanic reactivity, ozone is destroyed so rapidly in the ocean surface layer that ocean turbulence has no enhancing effect on deposition velocity.

2.2.3. Sensitivity of Deposition Velocity to Sea-Surface Temperature (SST). As mentioned in Section 2.1, the Fairall et al. [13] parameterisation has been constrained to allow for variation of ozone diffusivity in water due to temperature [30] and salinity [33] and variation of ozone solubility with temperature [34]. Using box model simulations, the effect of SST on the deposition velocity was investigated for typical North Eastern Atlantic conditions (wind speed of $8 \mathrm{~m} \mathrm{~s}^{-1}$ and oceanic reactivity of $500 \mathrm{~s}^{-1}$ ). See Figure 3 .

Results from box-model simulations confirm that inclusion of temperature dependence of molecular diffusivity renders the simulated deposition velocities less sensitive to SST variations. From Figure 3, the slope of the relationship between ozone deposition velocity and SST is 50\% steeper when the effect of SST on molecular diffusivity of ozone is not considered; in this case, the computed deposition velocities are likely to be oversensitive to SST. As discussed in the introduction to this paper, the effect of including variability of ozone diffusivity with SST is thought to compensate for the limiting effect of low-ozone solubility on simulated ozone deposition velocities, compared to the results of the global model study of Ganzeveld et al. [5].

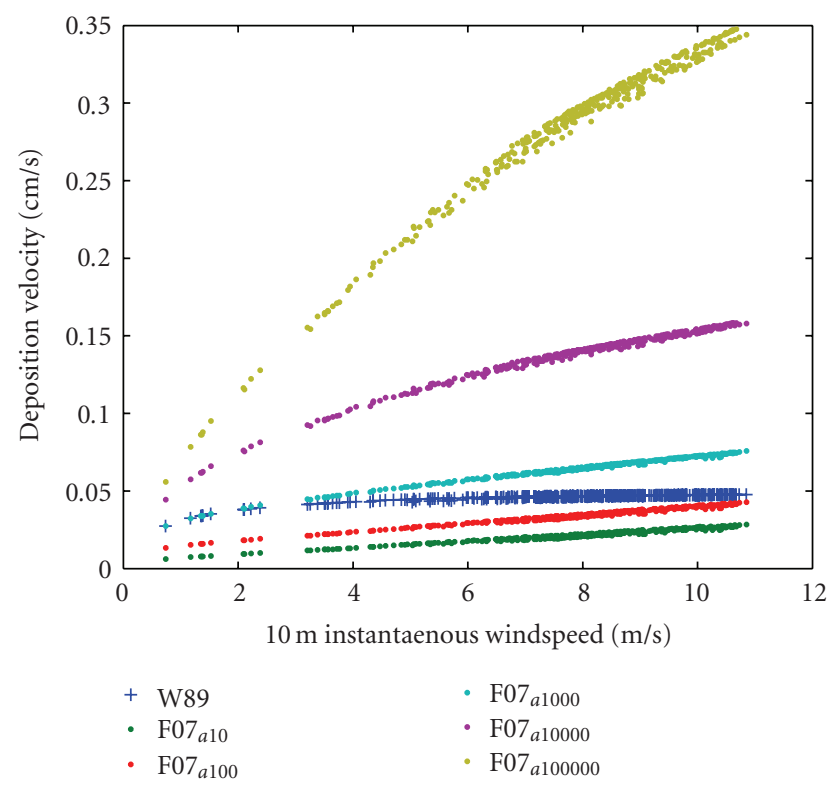

FIGURe 2: Deposition velocities computed from the Fairall et al. [13] (F07) and Wesely [18] (W89) schemes running within REMOTE. In the figure legend above, the subscript following the F07 label refers to the reactivity time-scale factor in operation for that scheme.

2.3. Chemical Scaling of the Reactivity Term. Accounting for chemical reactions in the Fairall et al. [13] parameterisation requires scaling of the chemical reactivity term $A_{\mathrm{oz}}$, as defined in (1). In their exploration of impact of chemical reactions on ozone deposition, Chang et al. [20] identified iodide as the most likely chemical compound residing in the sea surface to drive ozone deposition compared to other substances (DMS, alkenes). DMS was recognised as having potential to enhance ozone deposition, but only at extreme oceanic concentrations. At mean oceanic concentrations of DMS, deposition velocity due to molecular gas transfer and chemical reactions of ozone with DMS was an order of magnitude lower than the deposition velocity due to molecular diffusion and chemical reactions of ozone and iodide and deposition velocity due to molecular gas transfer. Reactions of ozone and alkenes were a further two orders of magnitude lower again. For this reason, reactions of ozone with DMS and alkenes were not considered in this study, their chemically enhancing effects on ozone deposition being overshadowed by iodide reactions. Chang et al. [20] did not investigate the effect of chlorophyll on ozone deposition which Clifford et al. [23] found to have a significant enhancment effect of the same order of magnitude as for iodide reactions. In this study, analysis of chemical enhancement to ozone deposition is limited to iodide and chlorophyll reactions.

2.3.1. Iodide Reactions. To scale $A_{\mathrm{oz}}$, the kinetics between ozone and it's various reactants needed to be determined. The enhancing effect of iodide reactions on ozone deposition has been long documented $[20,21]$. From the kinetics 


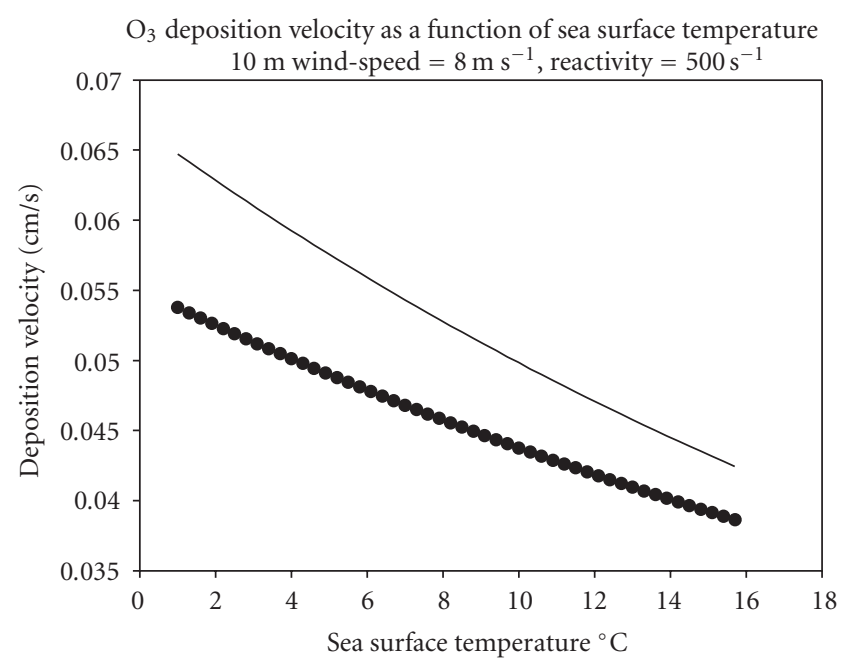

- Diffusivity and solubility vary with SST $v_{d}=0.05-0.001 \mathrm{~T}\left({ }^{\circ} \mathrm{C}\right), R^{2}=0.997$

- Solubility varies with SST $v_{d}=0.07-0.0015 T\left({ }^{\circ} \mathrm{C}\right), R^{2}=0.996$

Figure 3: Box-model-derived relationship between deposition velocity and sea-surface temperature, using a typical Atlantic wind speed of $8 \mathrm{~m} \mathrm{~s}^{-1}$ and reactivity of $500 \mathrm{~s}^{-1}$. The solid line depicts a relationship between deposition velocity and SST when only temperature dependence of ozone solubility in seawater is considered based on the theory of Kosak-Channing and Helz [34]. The filled circles represent a relationship between deposition velocity and SST when temperature dependence of both ozone solubility and molecular diffusivity in seawater is considered. Variation of ozone diffusivity in seawater is based on the theory of Johnson and Davis [30] and Jahne et al. [31]. Linear correlations between ozone deposition velocity and SST are given in the legend.

of the ozone-iodide reaction derived by Magi et al. [29], relationships between ozone-iodide rate constant and water salinity were derived for different water temperatures. From this, a relationship between the second order reaction rate $k_{\text {salt }}$ and saline water temperature $T$ was deduced for water of ionic strength of seawater $(0.7 \mathrm{M})$ resulting in the linear relationship of (2), where $k_{\text {salt }}$ refers to the reaction rate of ozone in salt water of ionic strength $0.7 \mathrm{M}$ and $T$ refers to water temperature in degrees Kelvin

$$
k_{\text {salt }}\left(10^{9} \mathrm{~s}^{-1}\right)=-40.85+0.15 T(\mathrm{~K}) .
$$

From the work of Magi et al. [29], the effect of salinity enhances ozone-iodide reaction rates by as much as $23 \%$ compared to those for pure water, and so it was considered important to account for the salinity of seawater in parameterising ozone-iodide reactions.

Oceanic iodide concentrations in the North Atlantic vary between 0 and $150 \mathrm{nM} \mathrm{[35].} \mathrm{For} \mathrm{this} \mathrm{study,} \mathrm{constant} \mathrm{iodide}$ concentrations were varied between $50 \mathrm{nM}$ and $200 \mathrm{nM}$ to evaluate the sensitivity of simulated ozone levels and resulting ozone fluxes to the effect of changing iodide concentrations, in contrast to the global modelling study of Ganzeveld et al. [5] who infer oceanic concentrations using

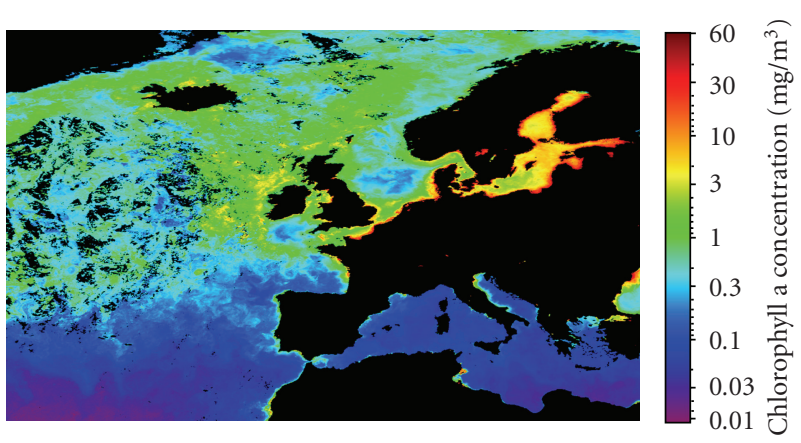

FIGURE 4: Monthly averaged chlorophyll-a concentration $\left(\mathrm{mg} \mathrm{m}^{-3}\right)$, as detected by MODIS for June, 2003. Taken from the NASA OceanColor website (http://oceancolor.gsfc.nasa.gov/.)

an anticorrelation between nitrate and iodide developed by Campos et al. [36]. Furthermore, the global model study did not include the effect of salinity of seawater on ozone-iodide reaction kinetics, as is done in this study.

2.3.2. Organic Enhancement of Ozone Deposition. It has been long postulated that organic reactions in the sea surface layer can have a significant enhancing effect on ozone deposition [22]. Clifford et al. [23] suggest that the reaction between ozone and chlorophyll can increase ozone deposition velocity by up to a factor of 3 for wind speeds up to $20 \mathrm{~m} \mathrm{~s}^{-1}$ compared to deposition velocities computed solely on ozoneiodide reactions. Considering the ubiquity of chlorophyll in the ocean, the organic enhancement of ozone deposition could have a significant effect on ozone concentrations in the marine boundary layer. This organic enhancement of ozone deposition was mechanistically incorporated into the Fairall et al. [13] deposition scheme using satellite chlorophyll data from MODIS (moderate resolution imaging spectroradiometer) [37]. The upper and lower limits of oceanic chlorophyll concentrations were set to $3 \mathrm{mg} \mathrm{m}^{-3}$ and $0 \mathrm{mg} \mathrm{m}^{-3}$, respectively, and oceanic iodide concentration was set to a typical value of $100 \mathrm{nM}$. Figure 4 shows monthly averaged chlorophyll concentrations for June 2003, as detected by MODIS. Although chlorophyll values as high as $30 \mathrm{mg} \mathrm{m}^{-3}$ in coastal regions are visible in Figure 4, the upper limit of chlorophyll concentration was set to $3 \mathrm{mg} \mathrm{m}^{-3}$ because open ocean chlorophyll concentrations in the North East Atlantic do not exceed this value. Also, when the resolution of the model is taken into consideration, chlorophyll values averaged over a single grid cell never exceed $3 \mathrm{mg} \mathrm{m}^{-3}$, even in coastal areas. Therefore, $3 \mathrm{mg} \mathrm{m}^{-3}$ is a sensible upper limit for open ocean chlorophyll concentrations for this study.

Ozone deposition velocity was computed as before using the Magi et al. [29] iodide chemistry and increased according to a linear chlorophyll-dependent enhancement factor: deposition velocity increased by a factor of 3 at the upper limit of chlorophyll concentration values. Deposition velocity was left unchanged at the lower limit of chlorophyll concentration where deposition velocity was based only on iodide chemistry. 
The technique employed in this study differs from that of Ganzeveld et al. [5] who applied linear dependence of reactivity term $A_{\mathrm{oz}}$ on chlorophyll concentrations whereas in this study, the deposition velocity increases linearly with chlorophyll and the organic reactions are not represented in $A_{\mathrm{oz}}$. This organically enhanced version of the Fairall et al. [13] deposition scheme is herein referred to as the mechanistic ozone deposition scheme.

This scaling is a crude approach to the quantification of organic reactions in the computation of ozone deposition velocity and should be interpreted as a first-order representation of organic chemistry within the Fairall et al. [13] scheme, oceanic chlorophyll concentration being used as a proxy for biological activity. Further work is needed to parameterise the role of organic reactions in ozone deposition.

2.4. Ozone-Deposition Driven Upward Iodine Flux. The major source of iodine to the atmosphere is most likely due to emission of organoiodine compounds from the ocean [38]. Martino et al. [8] have recently shown that a proportion of organic iodide found in the marine atmosphere can be formed from volatile organoiodine compounds (VOIs) which are produced via ozone-iodide reactions in the sea surface, thereby uncovering a potentially significant iodine source to the marine atmosphere which is kick started by the deposition of ozone to the sea surface. The VOI species identified by Martino et al. [8] resulting from ozone deposition are $\mathrm{CH}_{2} \mathrm{I}_{2}, \mathrm{CH}_{2} \mathrm{ICl}$, and $\mathrm{CHI}_{3}$. Based on the findings of Martino et al. [8] and the work of Garland et al. [21], the extreme upper limit of iodine vapours released to the atmosphere can be estimated from the ozone flux of ozone to the ocean, assuming all of the new VOIs are emitted from the ocean surface, without any being transported to the ocean mixed layer or being destroyed by photolysis at the sea-air interface. This newly defined halogen source in the marine boundary layer could have significant biogeochemical consequences, in terms of both marine boundary layer (MBL) ozone depletion and new particle formation.

\section{Simulation Results and Discussion}

Monthly REMOTE simulations were carried out for the month of June, 2003. The model domain spans Northern Europe and is depicted in Figure 11. Resolution of the model is set to $0.5 \mathrm{deg}$, giving an average grid cell size of $50 \mathrm{~km}$ $\times 50 \mathrm{~km}$. Meteorological and chemical initial and boundary conditions are taken from ECMWF (European Centre for Medium-Range Weather Forecasts) and used to initialise all grid points at the start of each simulation. Lateral boundaries are enforced at six hourly intervals and emission scenarios were supplied from the EMEP site. In 2003, monthly average chlorophyll concentrations in the North East. Atlantic were at an annual peak in the month of June [37].

3.1. Ozone Concentration Fields. Figure 5 shows surface level mean monthly ozone concentrations simulated using different deposition schemes within REMOTE. There is little or no difference between simulated surface level ozone concentrations using the nonchemical Wesely [18] scheme and the Fairall et al. [13] scheme for $50 \mathrm{nM}$ or $200 \mathrm{nM}$ iodide concentrations, consistent with findings of the global model study of Ganzeveld et al. [5]. One can conclude from this that ozone concentrations predicted using the Fairall et al. [13] scheme within REMOTE are insensitive to iodide reactions at realistic Atlantic iodide concentrations-even at an upper limit of oceanic iodide concentration of $200 \mathrm{nM}$. Therefore, although variation in iodide concentration and reaction rate causes variation in ozone deposition velocity, these deposition velocities are not sufficiently significant to overcome other compensating effects in the climate model and substantially decrease simulated ozone concentrations. However, a notable decrease in ozone concentrations is observed around the North East Atlantic when the mechanistic ozone deposition scheme of Fairall et al. [13] is employed. Simulated ozone depletion in this region is due to the relatively high chlorophyll concentrations. In regions of low oceanic chlorophyll concentration (e.g., the Mediterranean), the mechanistic ozone deposition scheme models similar ozone concentrations as computed using the Wesely [18] scheme.

Figure 6 depicts ozone concentrations in the North East. Atlantic region as predicted by REMOTE using three permutations of the Fairall et al. [13] scheme and using the nonchemical Wesely [18] scheme. The Fairall et al. [13] scheme including $100 \mathrm{nM}$ iodide chemistry predicts ozone concentrations similar to those simulated using the Wesely [18] scheme. The impact of chlorophyll on simulated ozone levels in this region can be seen by comparing the mean monthly ozone levels simulated using the Fairall et al. [13] scheme scaled to include iodide chemistry alone (100 nM I scheme), and the mechanistic version scaled to include both iodide chemistry and organic reactions. Ozone levels simulated by the mechanistic dry deposition scheme are as much as $15 \mathrm{ppb}$ lower than ozone levels simulated by both the Wesely [18] scheme and the $100 \mathrm{nMI}$ scheme. The Fairall et al. [13] 100 nM I scheme and the mechanistic scheme differ only by organic enhancement of deposition velocity and so the lower ozone concentrations simulated by the mechanistic schemes are due to inclusion of organic chemistry alone.

Figure 7 compares ozone concentrations measured at the Mace Head atmospheric research station measurement site off the west coast of Ireland to modelled ground-level ozone concentrations in this region. Ozone levels were measured at Mace Head using a continuous ozone analyser by UV photometry. See Tripathi et al. [39] for full description of this data and measurements. All simulated ozone concentrations agree quite well with observations, but the Mace Head ozone concentrations simulated by the mechanistic scheme correlate better with the observed ozone concentrations than other schemes. The root mean square (RMS) deviation between in situ ozone measurements at Mace Head and modelled ozone concentration for this region was $7.7 \mathrm{ppb}$ when using the mechanistic scheme whereas the next closest correlations were obtained using the Fairall et al. [13] 


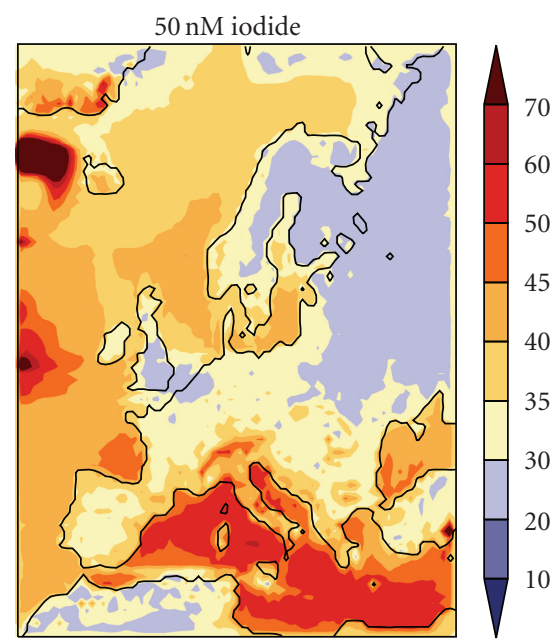

(a)

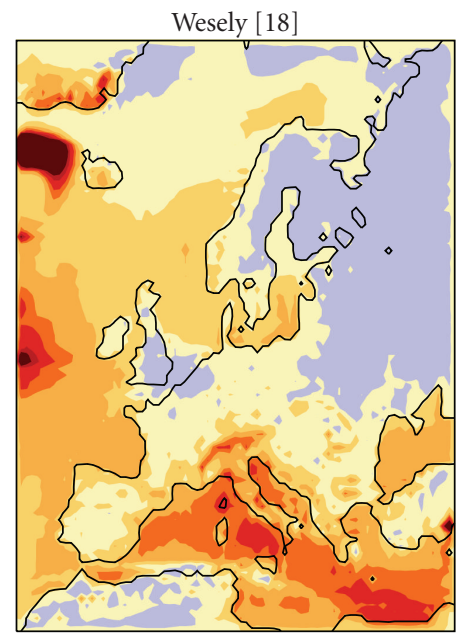

(c)

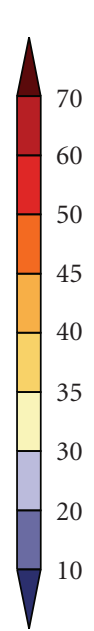

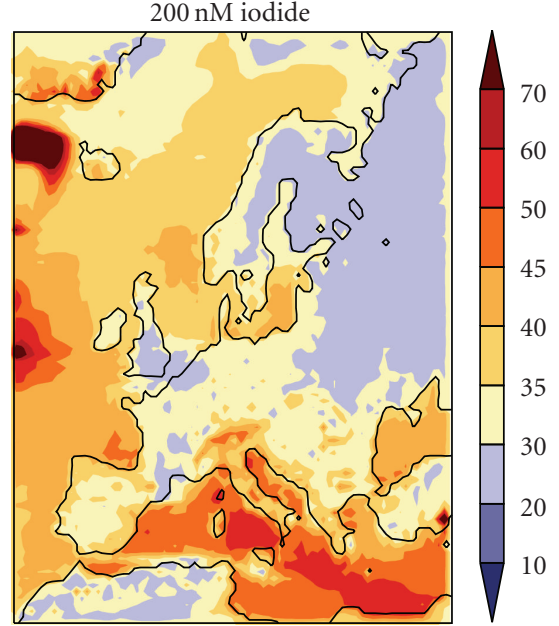

(b)

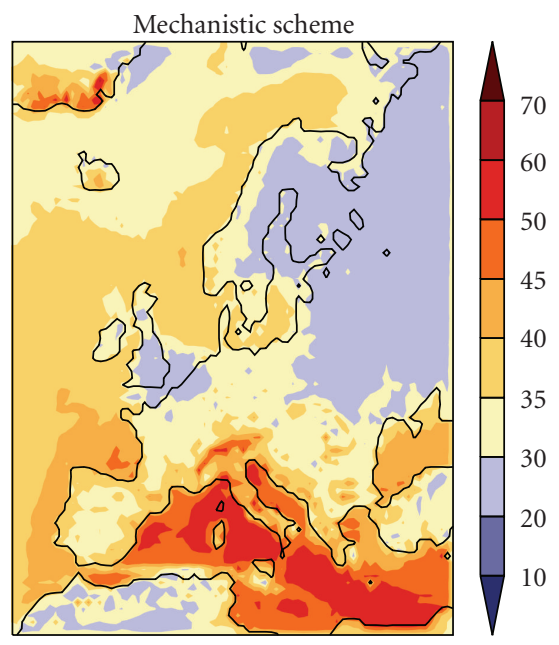

(d)

FIGURE 5: Monthly average $\mathrm{O}_{3}$ concentrations in ppb as predicted by REMOTE for June 2003 for various dry deposition schemes. 50 nM I plot and $200 \mathrm{nM}$ I plot show simulated ozone concentrations (ppb) using the iodide-only chemical Fairall et al. [13] parameterisation with oceanic iodide concentrations set to $50 \mathrm{nM}$ and $200 \mathrm{nM}$, respectively. The Wesely [18] plot shows the ozone concentrations simulated by the nonchemical scheme and the Mechanistic Scheme plot depicts the $\mathrm{O}_{3}$ concentrations simulated using the Fairall et al. [13] scheme with inclusion of a first-approach chlorophyll-based organic chemistry.

scheme with reactivity set to $1000 \mathrm{~s}^{-1}$, and the Wesely [18] scheme which gave RMS deviations of $9.1 \mathrm{ppb}$ and $11.6 \mathrm{ppb}$, respectively. This shows that on average, deviations between simulated ozone concentrations and in situ measurements are less for results obtained using the mechanistic ozone dry deposition scheme than those generated using other dry deposition schemes. However, firm conclusions on accuracy of dry deposition parameterisation cannot be drawn here, as simulated ozone-mixing ratio is dependent on other model processes including atmospheric chemistry, transport, and boundary conditions. In addition, the in situ measurements represent a point measurement of ozone-mixing ratio, whereas the model output represents average ozone mixing ratio over a grid cell which spans $50 \mathrm{~km} \times 50 \mathrm{~km}$. In this analysis, attempts have been made to account for this by comparing modelled ozone concentrations with in situ ozone measurements averaged over 1.75 hours, the time taken for an air mass to traverse the length of one grid cell $(50 \mathrm{~km})$, assuming an average easterly wind speed of $8 \mathrm{~m} \mathrm{~s}^{-1}$. However, localised effects influencing ozone concentrations at Mace Head will not be represented in model simulations due to the effect of averaging over the grid cell area and so simulated ozone concentrations will not have the same variation as ozone measurements at Mace Head. This would explain large variations between simulated and measured ozone concentrations for example, measurements between Julian Day 166 and 171 are much lower than all model results.

From Figure 7, it can be seen that the $100 \mathrm{nM}$ I Fairall et al. [13] scheme and the Wesely [18] scheme predict higher ozone concentrations than observations or other model set ups during periods of low-wind speeds (e.g., between days 165 and 171). The reactivity of the $100 \mathrm{nMI}$ scheme 


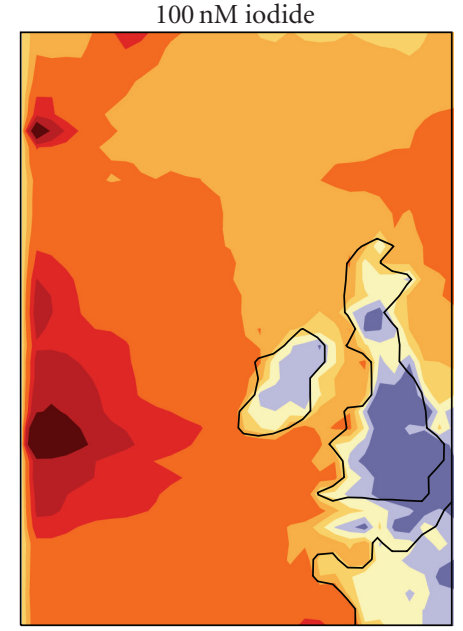

(a)

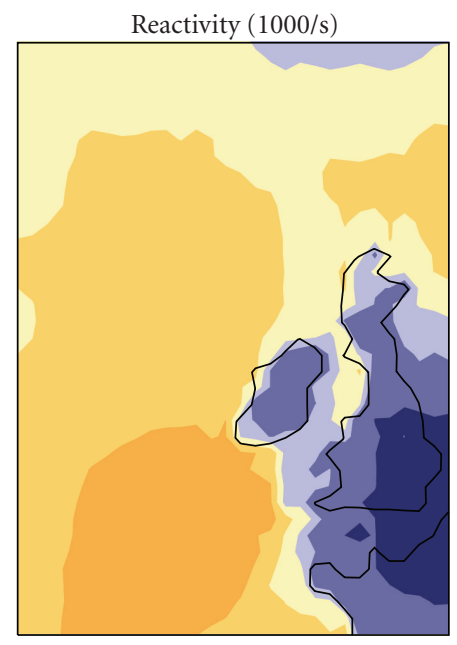

(c)

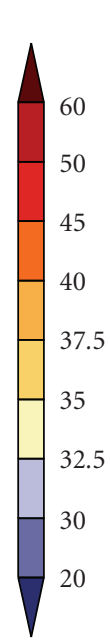

60

50

45

40

(

2.5

0
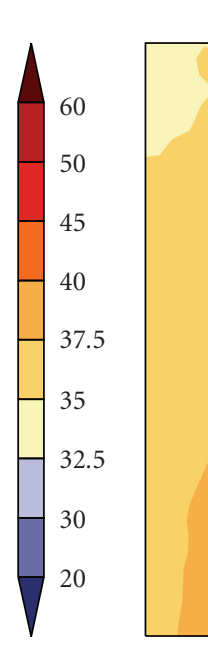

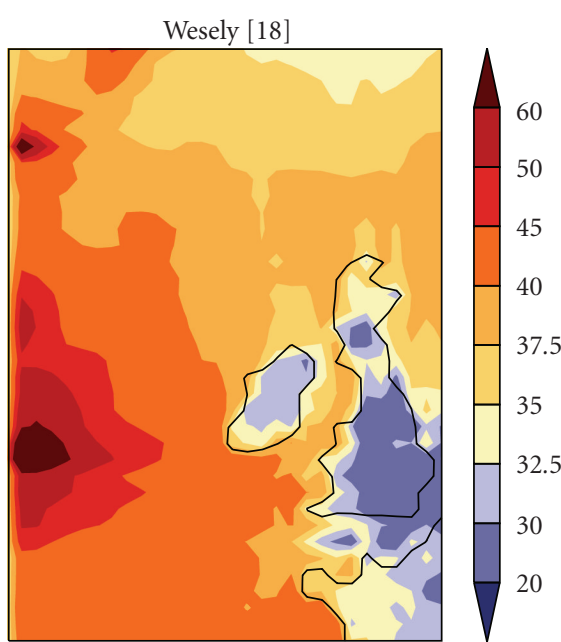

(b)

Mechanistic scheme

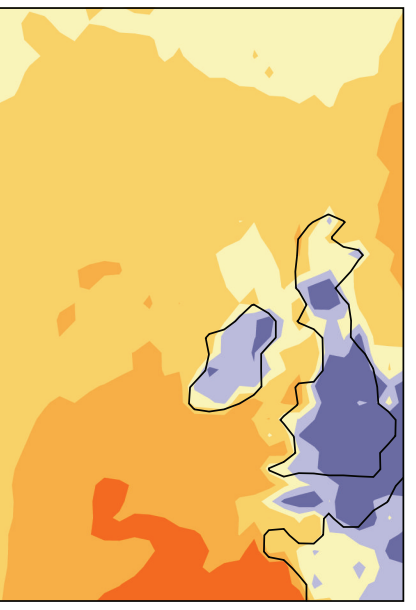

(d)

FIGURE 6: Monthly average $\mathrm{O}_{3}$ concentrations in ppb in the North East Atlantic region as predicted by REMOTE for June 2003 for various dry deposition schemes. $100 \mathrm{nM}$ I plot depicts simulated ozone concentrations (ppb) using the iodide-only chemical parameterisation of Fairall et al. [13] with oceanic iodide concentrations set to $100 \mathrm{nM}$. The Wesely [18] plot shows the ozone concentrations simulated by the nonchemical scheme. Reactivity 1000/s plot shows ozone concentrations simulated using the Fairall et al. [13] scheme with reactivity term set to constant $1000 \mathrm{~s}^{-1}$ and mechanistic scheme plot depicts the ozone concentrations simulated using the Fairall et al. [13] scheme with inclusion of first-approach chlorophyll-based organic chemistry.

is not large enough to account for ozone water surface transfer at low-wind speed and the Wesely [18] scheme does not account for chemical ozone transfer at all. Therefore, using either of these schemes, REMOTE over predicts ozone concentrations at periods of low-wind speed.

Simulations using the Fairall et al. [13] scheme with constant reactivity set to $1000 \mathrm{~s}^{-1}$ predict very similar ozone concentrations around Mace Head to the simulations using the mechanistic scheme (reactivity due to $100 \mathrm{nM}$ Iodide and organic enhancement). Therefore, around the western Irish coast, it can be deduced that effect of organic chemistry causes oceanic reactivity of the order of $1000 \mathrm{~s}^{-1}$. Figure 8 shows monthly average values of deposition velocities computed for the various deposition schemes. In the mechanistic scheme, organic reactions are parameterised by increasing deposition velocity according to oceanic chlorophyll concentration, and so organic reactions are not represented in the reactivity term, $A_{\mathrm{oz}}$ of the Fairall et al. [13] parameterisation. However, by comparing average deposition velocities depicted in Figure 8 with relationship between reactivity and deposition velocity shown in Figures 1 and 2, it can be deduced that the deposition velocities obtained around the Irish coast using the mechanistic scheme $\left(0.6-0.1 \mathrm{~cm} \mathrm{~s}^{-1}\right)$ would require reactivity values exceeding $1000 \mathrm{~s}^{-1}$, assuming moderate windspeeds. Variation of $V_{d}$ in the Wesely [18] scheme and the Reactivity $1000 \mathrm{~s}^{-1}$ scheme occurs due to turbulent effects alone.

3.2. Ozone-Loss Rate. The loss rate of ozone from the mixing volume to the ocean due to dry deposition was calculated in 


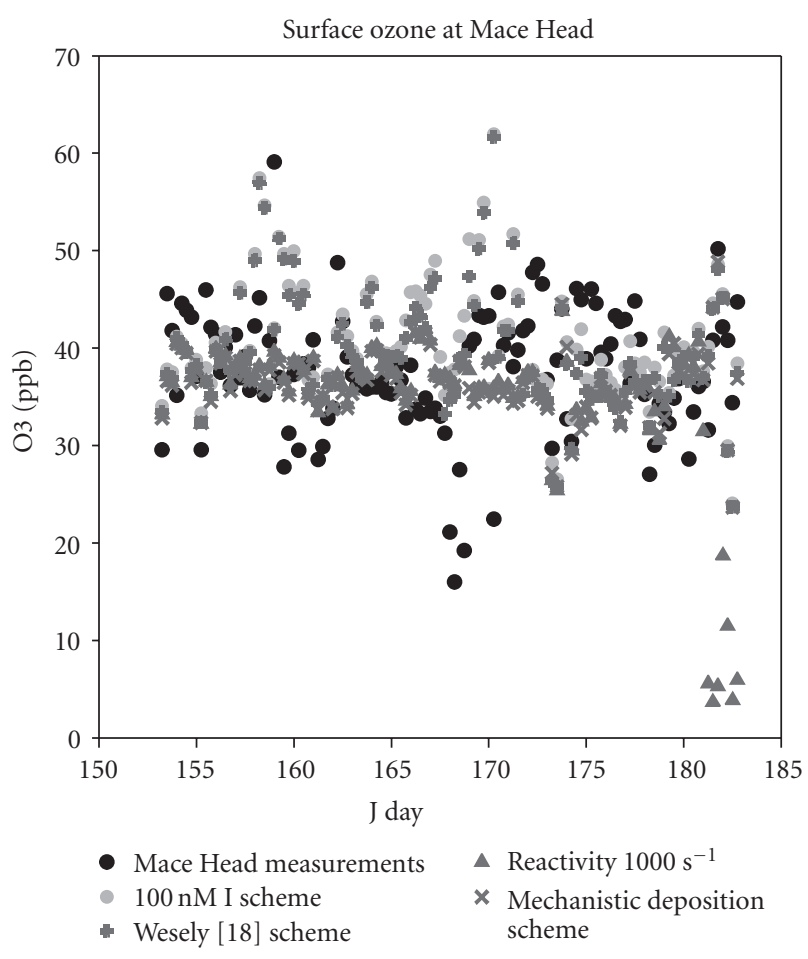

FIgUre 7: Ozone concentrations (ppb) simulated by REMOTE and measured ozone concentrations (ppb) at Mace Head for June 2003.

order to assess the impact of varying ozone deposition on the rate of atmospheric ozone loss to the ocean as a result of dry deposition and the consequential effect on ambient ozone concentration. The loss rate is given by

$$
\text { Loss Rate }=\frac{F_{O 3}}{L},
$$

where $F_{O 3}$ is the dry deposition flux of ozone to the ocean (the product of deposition velocity and ambient ozone concentration) and $L$ is the boundary layer height. Deposition velocities and ozone concentrations were extracted from REMOTE and boundary layer height taken as a constant $800 \mathrm{~m}$. Figure 9 shows ozone-loss rates computed for the various dry deposition schemes.

A higher deposition velocity does not necessarily denote a higher ozone-loss rate, as the loss rate is proportional to both ozone concentration and deposition velocity.

The loss rate of ozone to the ocean varies with oceanic iodide concentration as seen from the first two plots of Figure 9, using the iodide-only constrained scheme of Fairall et al. [13]. This occurs due to the different deposition velocities generated from the dry deposition schemes based on reactivity. However, it can be seen that the variation of the iodide concentration has no significant effect on ground level ozone concentration and so the variation in ozone-loss rate due to differences in iodide concentration is too subtle to have a bearing on ambient ozone concentrations, indicating the dominance of other processes over the dry deposition sink in regulation of ambient boundary layer ozone concentrations within REMOTE for lower dry depositional loss rates.

The Wesely [18] scheme predicts a greater ozone-loss rate than the mechanistic ozone deposition scheme. This occurs due to the depletion of ambient ozone concentrations because of enhanced dry deposition in the presence of marine biological activity.

3.3. Upward Iodine Flux. $20 \%$ of ozone deposited to the sea surface reacts with iodide [21]. $1 \%$ of iodide oxidised by ozone reacts with organic matter to form the VOIs $\left(\mathrm{CH}_{2} \mathrm{I}_{2}\right.$, $\mathrm{CH}_{2} \mathrm{ICl}$, or $\mathrm{CHI}_{3}$ ) that are released from the sea surface [8]. The upper limit of potential iodine flux to the marine atmosphere as a result of ozone deposition is predicted using these relationships. Resulting VOI fluxes are shown in Figure 10. The upward VOI flux is derived directly from the downward ozone flux, and so the same factors influence both the downward ozone flux and the upward iodine flux. The upward VOI flux also varies with oceanic iodide concentration. It is stressed that this potential VOI flux to the atmosphere represents an extreme upper limit, and is to be interpreted as such.

The upward VOI flux predicted using the Wesely [18] scheme exceeds that predicted by the Fairall et al. [13] scheme constrained by iodide reactions. The mechanistic ozone dry deposition scheme predicts VOI flux exceeding that predicted using Wesely [18] in some regions ( north east of Britain) while the flux is less than that predicted using Wesely [18] in other areas (off the southern Irish coast).

This ozone deposition-driven flux of iodine from the ocean is likely to have significant biogeochemical consequences. Marine aerosols and cloud condensation nuclei (CCN) can be formed from iodine vapours in coastal environments $[11,40]$. The addition of new aerosols to the coastal atmosphere could have a significant impact on the global solar radiation budget due to their role in scattering of incoming solar radiation, and therefore accurate prediction of the VOI flux is imperative in predicting future climatic scenarios. To fully assess the atmospheric implications of this extra iodine source in the MBL, the upward organoiodine flux and resulting chemical reactions and particle formation would have to be included in the chemical scheme of REMOTE.

3.4. Area-Averaged Study of Simulation Results. A quantitative comparison of simulation results using the various dry deposition schemes was performed by taking an area average of various parameters over a boxed region in the North Atlantic, off the Irish coast - a region of relatively high biological activity. The region is displayed in Figure 11. In this area, average, maximum, and minimum deposition velocities from the various schemes were compared, as were the average simulated ozone concentrations, average ozoneloss rates, average upward VOI flux and derived average increase in the daily rate of the VOI-mixing ratio. Results are tabulated in Table 1 . 


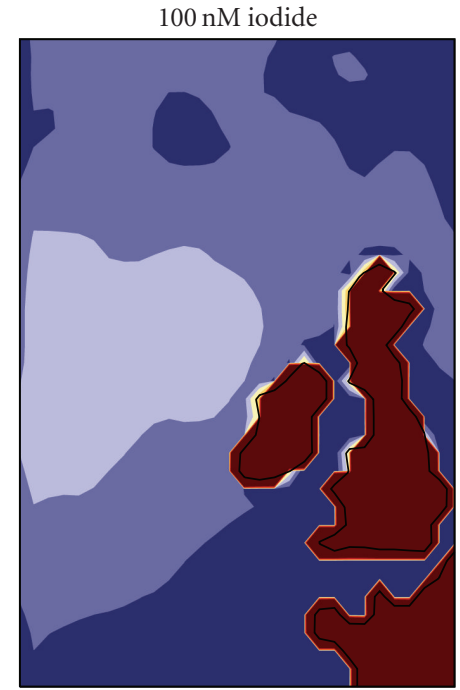

(a)

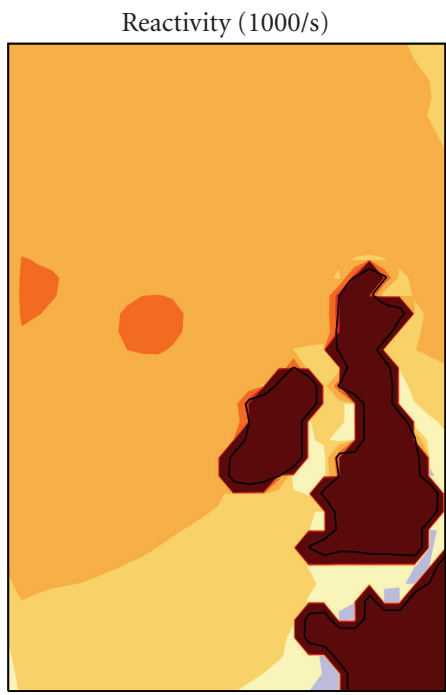

(c)
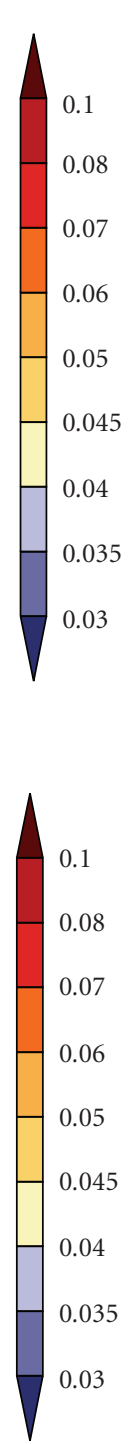

(c)

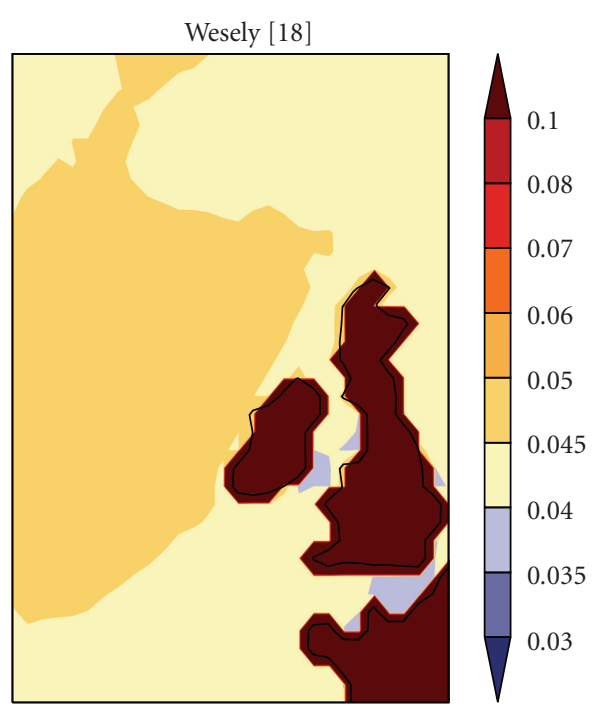

(b)

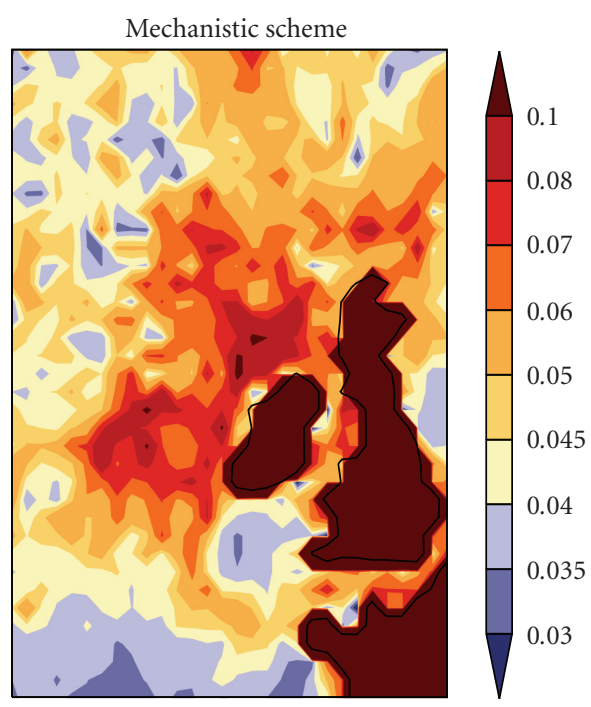

(d)

FIGURE 8: Monthly mean deposition velocity in the North East Atlantic region as predicted by REMOTE for June 2003 for various dry deposition schemes. $100 \mathrm{nM}$ I plot depicts deposition velocity using the Fairall et al. [13] parameterisation with oceanic iodide concentrations set to $100 \mathrm{nM}$. The Wesely [18] plot shows deposition velocity simulated by the nonchemical scheme. Reactivity 1000/s plot shows deposition velcity simulated using the Fairall et al. [13] scheme with reactivity term set to constant $1000 \mathrm{~s}^{-1}$ and mechanistic scheme plot depicts the deposition velocity simulated using the Fairall et al. [13] scheme with inclusion of first-approach chlorophyll-based organic chemistry.

3.4.1. Deposition Velocity. Deposition velocities simulated using the Fairall et al. [13] parameterisation vary with oceanic iodide concentration, but as we have seen earlier, these variations are too subtle to have a significant effect on ambient ozone concentrations. The mechanistic scheme computes deposition velocities in this region exceeding those computed using the [18] scheme by $18 \%$. Neither the Wesely [18] scheme nor the Fairall et al. [13] scheme constrained to iodide chemistry can account for deposition velocities as high as the observations of Gallagher et al. [17]. Surface resistance is set to a constant $2000 \mathrm{~m}^{-1} \mathrm{~s}$ in the Wesely [18] scheme, and so maximum deposition velocity computed by this scheme deviates very little from the average deposition velocity; using this nonchemical scheme, deposition velocities cannot match the upper limit of observations under any conditions.

Additional chemical reactions must be included in the dry deposition scheme in order to realise deposition velocities as high as observations. Only the mechanistic ozone deposition scheme predicts deposition velocities higher than observations of Gallagher et al. [17]. Therefore, only by integration of organic chemistry into the dry deposition scheme can deposition velocities as high as observations be realised. 


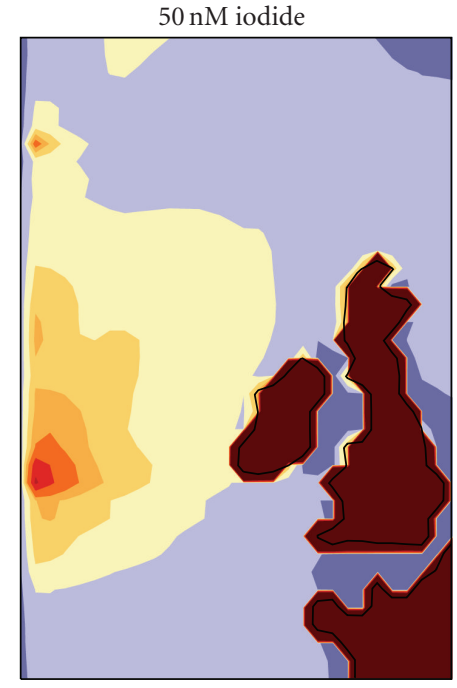

(a)

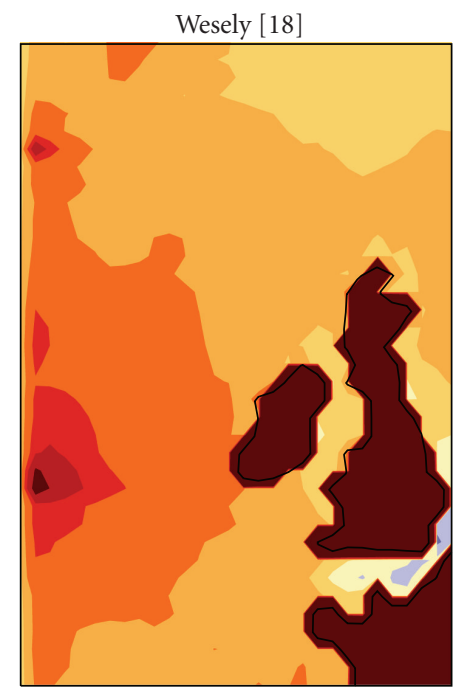

(c)
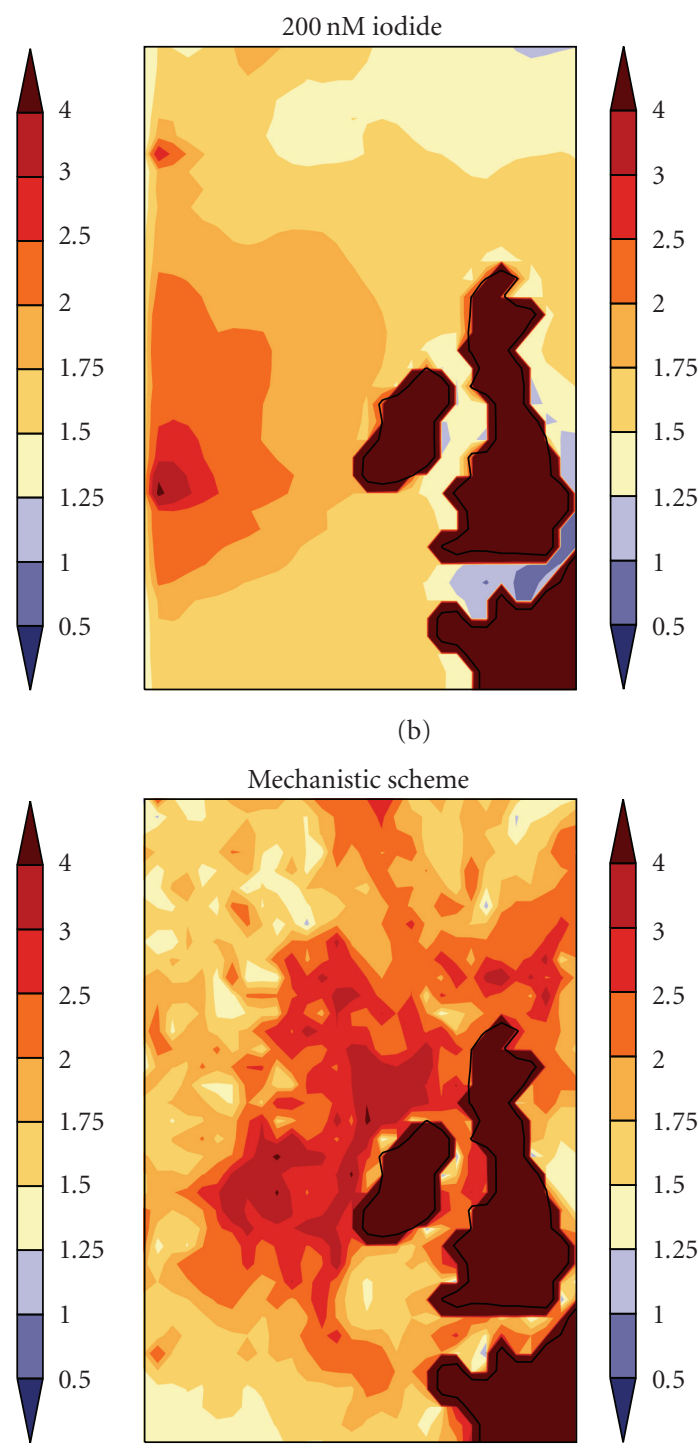

(d)

FIGURE 9: Monthly mean $\mathrm{O}_{3}$ loss rates (ppb per day) as predicted by REMOTE June 2003 for various dry deposition schemes. Simulated loss rates using the Fairall et al. [13] parameterisation with oceanic iodide concentrations set to $50 \mathrm{nM}$ and $200 \mathrm{nM}$, respectively, are shown. The Wesely [18] plot shows the ozone-loss rates simulated by the nonchemical Wesely [18] scheme and the mechanistic scheme shows the $\mathrm{O}_{3}$ loss rate simulated using the Fairall et al. [13] scheme with inclusion of first-approach chlorophyll-based organic chemistry.

3.4.2. Ozone Concentration. Simulated average ozone concentrations in this area are relatively insensitive to oceanic iodide concentration. Inclusion of first-order organic chemistry parameterisation based on Clifford et al. [23] into the dry deposition parameterisation causes a decrease in simulated ozone concentration in the area of $20.5 \%$ or $9.5 \mathrm{ppb}$ compared to concentrations simulated using the Wesely [18] scheme. This increase in ozone deposition occurs due to the enhancement of ozone deposition velocity due to inclusion of organic reactions in the mechanistic ozone deposition scheme, as discussed above. The Wesely [18] scheme predicts an average ozone concentration in this area $1.6 \%$ lower than that predicted using the Fairall et al.
[13] parameterisation constrained by an oceanic iodide concentration of $100 \mathrm{nM}$.

3.4.3. Ozone-Loss Rate. Average ozone-loss rate computed by Wesely [18] exceeds that computed by the mechanistic ozone deposition scheme by nearly $6 \%$ in this region. The lower loss rate is due to the lower ambient ozone concentrations in the boundary layer due to organic enhancement of ozone deposition computed by the mechanistic ozone deposition scheme. The less reactive scheme constrained only by iodide reactions also computes ozone-loss rate less than that of the Wesely [18] scheme due to the higher deposition velocity 

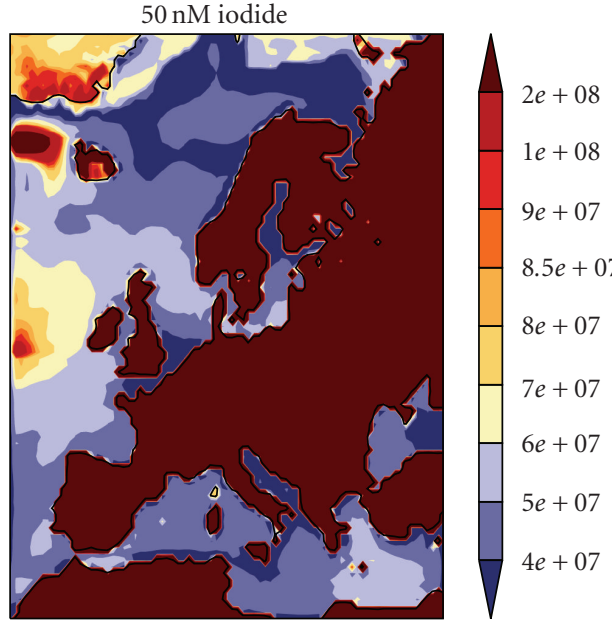

(a)

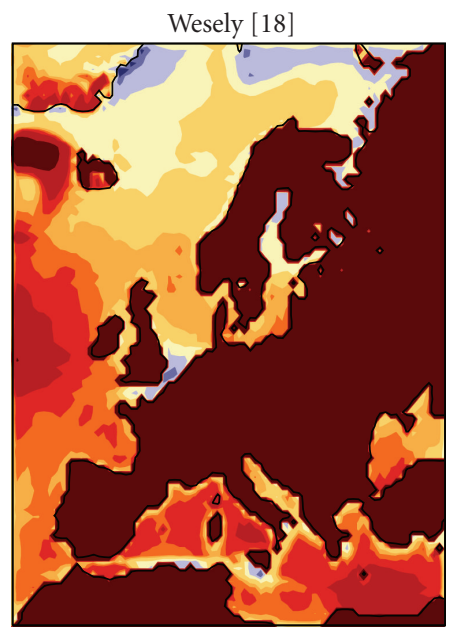

(c)

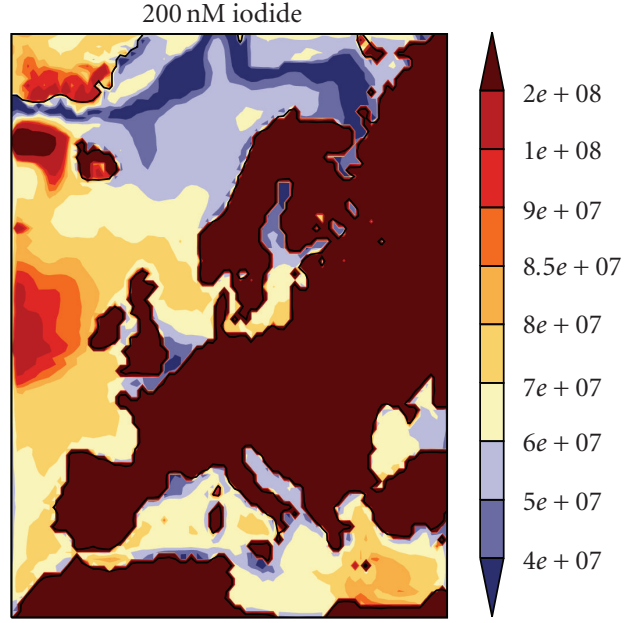

(b)

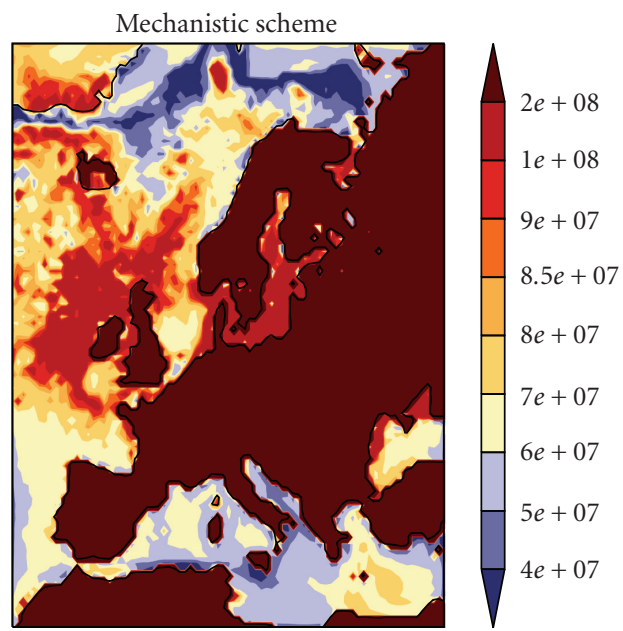

(d)

FIGURE 10: Monthly average upward iodine flux in molecules per $\mathrm{cm}^{-2} \mathrm{~s}^{-1}$, as predicted by REMOTE for June 2003 shown for the European region. Simulated flux using the Fairall et al. [13] parameterisation with oceanic iodide concentrations set to $50 \mathrm{nM}$ and $200 \mathrm{nM}$, respectively, are shown. The Wesely [18] plot shows the flux simulated by the nonchemical Wesely [18] scheme and the mechanistic scheme shows the flux simulated using the Fairall et al. [13] parameterisation using a first-approach organic chemistry scaling.

computed by the Wesely [18] scheme. The relatively small changes in loss rates are shown not to have a large effect on ambient ozone concentrations in REMOTE, but accurate estimation of ozone dry deposition flux is necessary to evaluate ozone-deposition driven upward VOI flux.

3.4.4. Potential Upward VOI Flux. This flux is estimated linearly from the downward ozone flux. The simulated potential VOI flux emitted from the ocean in this area is of the order of $10^{8}$ molecules $\mathrm{cm}^{-2} \mathrm{~s}^{-1}$. Martino et al. [8] compute a typical downward depositional iodine flux of $3 \times 10^{7}$ atoms $\mathrm{cm}^{-2} \mathrm{~s}^{-1}$. The potential upward VOI flux exceeds the depositional iodine flux, thus constituting a significant additional source of atmospheric iodine in marine environments, especially in regions of high biological activity when organic enhancement of ozone deposition is factored into the dry deposition parameterisation.
3.4.5. Increase of VOI-Mixing Ratio. Recent measurements of iodocarbon fluxes taken in the North East. Atlantic [41] have found open ocean sea-air fluxes of the ozone-deposition derived VOIs $\left(\mathrm{CH}_{3} \mathrm{I}, \mathrm{CH}_{2} \mathrm{I}_{2}\right.$, and $\left.\mathrm{CH}_{2} \mathrm{ICl}\right)$ as high as $9.6 \times 10^{7}$ molecules $\mathrm{cm}^{-2}$ day $^{-1}$, which would lead to a mixing ratio increase of $4.24 \mathrm{ppt}$ per day. The average flux value observed in this region would lead to a VOI increase of $1.2 \mathrm{ppt}$ per day. In the more biologically active shelf and coastal regions, measured VOI sea-air fluxes have been measured that would result in mixing ratio increases as high as $9.3 \mathrm{ppt}$ per day and $18.1 \mathrm{ppt}$ per day, respectively. The measurements were taken in the biologically active regions off the west coast of Ireland where organic enhancement of ozone deposition is likely to occur.

The average simulated increase of potential VOI-mixing ratio in this area is of the order of $4 \mathrm{ppt}$ per day and the range of ozone-driven iodocarbon flux in this region 
TABLE 1: Results from area average analysis carried out over a boxed region in the North Atlantic.

\begin{tabular}{|c|c|c|c|c|c|c|c|}
\hline Scheme & $\begin{array}{l}\text { Average } \\
\text { deposition } \\
\text { velocity } \\
(\mathrm{cm} / \mathrm{s}) \\
\end{array}$ & $\begin{array}{l}\text { Maximum } \\
\text { deposition } \\
\text { velocity } \\
(\mathrm{cm} / \mathrm{s}) \\
\end{array}$ & $\begin{array}{l}\text { Minimum } \\
\text { deposition } \\
\text { velocity } \\
(\mathrm{cm} / \mathrm{s}) \\
\end{array}$ & $\begin{array}{l}\text { Average [O3] } \\
\text { in ppb }\end{array}$ & $\begin{array}{c}\text { Average } \mathrm{O} 3 \\
\text { loss rate (ppb } \\
\text { per day) }\end{array}$ & $\begin{array}{l}\text { Average upward } \\
\text { VOI flux } \\
(\text { molecules } \\
\left.\mathrm{cm}^{-2} \mathrm{~s}^{-1}\right) \\
\end{array}$ & $\begin{array}{l}\text { Average mixing } \\
\text { ratio VOI } \\
\text { increase (ppt } \\
\text { per day) } \\
\end{array}$ \\
\hline Reactivity of $50 \mathrm{nM}$ Iodide & 0.0305 & 0.0509 & 0.00123 & 47.8647 & 1.57031 & $7.11 E+07$ & $3.14 E+00$ \\
\hline Reactivity of $100 \mathrm{nM}$ Iodide & 0.0355 & 0.0575 & 0.00127 & 47.5876 & 1.82221 & $8.26 E+07$ & $3.64 E+00$ \\
\hline Reactivity of $150 \mathrm{nM}$ Iodide & 0.0392 & 0.0623 & 0.00129 & 47.3911 & 2.0009 & $9.07 E+07$ & $4.00 E+00$ \\
\hline Reactivity of $200 \mathrm{nM}$ Iodide & 0.0421 & 0.0661 & 0.0013 & 47.2334 & 2.1445 & $9.72 E+07$ & $4.29 E+00$ \\
\hline Reactivity $1000 \mathrm{~s}^{-1}$ & 0.0573 & 0.0848 & 0.00134 & 36.6113 & 2.26644 & $1.03 E+08$ & $4.53 E+00$ \\
\hline Wesely [18] scheme & 0.0463 & 0.0488 & 0.0019 & 46.8433 & 2.34064 & $1.06 E+08$ & $4.68 E+00$ \\
\hline $\begin{array}{l}\text { Mechanistic scheme } \\
\text { (Reactivity of } 100 \mathrm{nM} \\
\text { Iodide and Organic } \\
\text { reactions) }\end{array}$ & 0.0547 & 0.161 & 0.00173 & 37.2185 & 2.20302 & $9.98 E+07$ & $4.40 E+00$ \\
\hline $\begin{array}{l}\text { Percentage difference } \\
\text { between Wesely [18] and } \\
\text { Mechanistic Scheme }\end{array}$ & -18.171 & -230.38 & 8.86149 & 20.5468 & 5.87979 & 5.87979 & 5.87979 \\
\hline $\begin{array}{l}\text { Percentage difference } \\
\text { between Wesely [18] and } \\
100 \mathrm{nM} \mathrm{I}^{-} \text {scheme }\end{array}$ & 23.1573 & -17.915 & 33.0857 & -1.5888 & 22.1493 & 22.1493 & 22.1493 \\
\hline
\end{tabular}

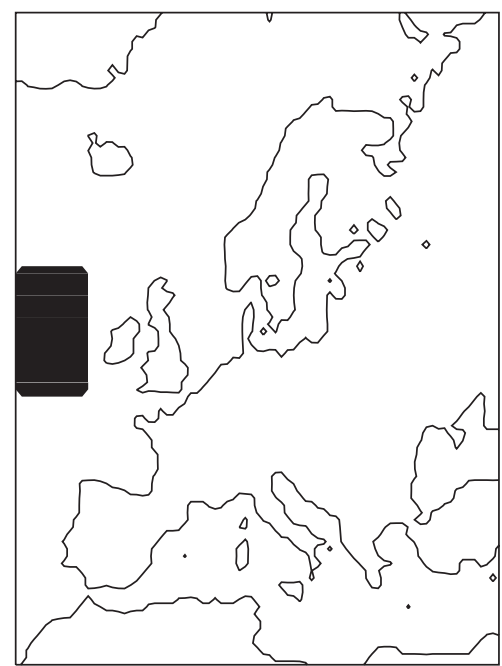

FIgURE 11: Location of boxed region in the North Atlantic off the west coast of Ireland in which the area-averaged analysis was performed.

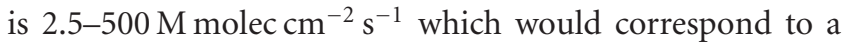
mixing-layer enhancement of VOI concentrations of $0.1-$ $22.0 \mathrm{ppt}$ per day. This enhancement to the mixing ratio was calculated using ideal gas theory and assuming a boundary layer height of $800 \mathrm{~m}$ and should be interpreted as the extreme upper limit of potential VOI flux occurring as a result of ozone deposition-in reality, a proportion of this flux would be mixed downwards and a further proportion will be photolysed at the sea surface [8]. Taking this into consideration, simulated VOI-mixing ratio enhancement is well within range of the recently observed iodocarbon fluxes [41], especially considering large iodocarbon fluxes observed in shelf and coastal regions. Considering the molar mixing ratio of total organic iodine ranges between 34 pptv in the boundary layer [42-44], even a small mixing ratio enhancement of these proportions would enhance atmospheric iodine concentrations considerably.

The extra iodine compounds released to the atmosphere could further add to ozone depletion in the marine boundary layer, thus forming a catalytic cycle of ozone destruction. Read et al. [45] investigated halogen-mediated ozone destruction over the tropical Atlantic Ocean and found that based on typical organic iodine molar mixing ratios of 3-4 ppt in the MBL [44], resulting IO concentrations of 1 ppt would cause ozone loss of $1.24 \mathrm{ppb}$ per day due to atmospheric reactions with IO. Crudely assuming a linear relationship between organic iodine concentrations and resulting ozone loss, additional influx of 22 ppt organic iodine per day into the mixing layer due to the ozonedeposition driven VOI flux would result in a further ozone loss of $7.8 \mathrm{ppb}$ per day. Even though this case represents the upper limit VOI flux to MBL, it is evident that the halogen-mediated ozone destruction cycle is likely to have significant consequences for ozone concentrations in the marine boundary layer, depleting ozone mixing ratios to the order of a ppb per day. To further investigate this feedback mechanism, REMOTE would need to be adapted to include halogen chemistry and the upward VOI flux. This is scheduled for further work.

\section{Conclusions}

Consistent with results of global model study conducted by Ganzeveld et al. [5], our results show that ozone 
concentrations predicted by the Fairall et al. [13] parameterisation within REMOTE are insensitive to realistic variations of oceanic iodide concentrations. Furthermore, the ozone concentrations predicted by this turbulent and chemically enhanced deposition scheme do not exceed those predicted by the highly parameterised Wesely [18] scheme when the parameterisation is constrained by iodide chemistry alone for typical oceanic iodide concentrations. In order for the new scheme to simulate deposition rates as high as field observations, oceanic reactivity must be in the order of $1000 \mathrm{~s}^{-1}$. The source of this extra reactivity is most likely due to ozone reacting with organic matter and chlorophyll in the sea surface $[22,23]$.

Deposition velocities as high as the observations of Gallagher et al. [17] were realised in regions of high biological activity using the mechanistic ozone deposition scheme, in which a crude first-approach scaling of organic ozone reactions was applied to the Fairall et al. [13] parameterisation. Use of this mechanistic ozone deposition scheme including organic reactions yielded boundary layer ozone concentrations much lower than those predicted using the highly parameterised, constant surface-resistance deposition scheme of Wesely [18]. This result is in contrast with findings of Ganzeveld et al. [5] who found the use of mechanistic approach to evaluation of surface resistance in fact reduced total dry deposition flux of ozone to the ocean compared to simulations ran using the Wesely [18] scheme with constant surface-resistance, even though the global model study incorporated additional chemical reactions of ozone with DMS, $\mathrm{C}_{2} \mathrm{H}_{4}$, and $\mathrm{C}_{3} \mathrm{H}_{6}$, which were deemed negligible in this study. However, variations between the global model results and results from this are most likely due to variation between the temporal and spatial resolution of the two model studies: the focus of this study is limited to a biologically active region for a time of year in which biological activity is at a maximum and so it would be expected that biochemical effects would be significant in resulting simulations. In contrast, the Ganzeveld et al. [5] study was performed on a global scale for a yearly period and simulated annual mean mixing ratios were analysed which would not reflect short-term seasonal effects. As stated in the introduction, the Wesely [18] scheme serves well in simulating ozone deposition for large-scale simulations, but the mechanistic Fairall et al. [13] parameterisation serves best for simulating ozone deposition velocity to the ocean for particular regional or seasonal effects, as in the case of high biological activity due to a phytoplankton bloom. In addition, Ganzeveld et al. [5] used variable inferred oceanic iodide concentration fields as opposed to constant oceanic iodide fields utilised in this study. Also, the global model study did not allow for the enhancing effect of high sea surface temperature (SST) on diffusivity of ozone in water and so ozone transfer in regions of high SST was limited by solubility and the enhancing effect of seawater salinity on ozone-iodide reaction kinetics was not considered in the global model study.

Based on the findings of this study, it is postulated that high ozone fluxes can be theoretically explained only by consideration of reactions of ozone with ocean dwelling organic matter.

Simulated ozone concentrations agree closely with in situ measurements at Mace Head. On average the mechanistic ozone deposition scheme displayed least deviation from measurements. This indicates a closer correlation between actual ozone concentrations and simulated ozone concentrations using the mechanistic scheme (RMS deviation of $7.7 \mathrm{ppb}$ ) than using the iodide-only scheme or the nonchemical Wesely [18] scheme (RMS deviation of $11.6 \mathrm{ppb}$ ).

Ozone dry deposition flux depends on both ozone concentration and deposition. Variations in ozone flux do not necessarily have a significant effect on ambient ozone concentration due to dominance of other model processes over the dry deposition processes at low deposition velocities.

To the best of authors' knowledge, this is the first study to use the advanced mechanistic ozone deposition scheme of Fairall et al. [13] to quantitatively evaluate the newly discovered ozone deposition-driven upward flux of iodine from the ocean outlined by Martino et al. [8], which is likely to have significant biogeochemical consequences. Ambient ozone concentrations are insensitive to oceanic iodide concentrations, but ozone dry deposition flux (and resulting upward iodine flux) varies with oceanic iodide concentration and so iodide reactions must be explicit within dry deposition models to adequately simulate biogeochemical consequences of dry depositional ozone flux.

\section{Acknowledgments}

The authors gratefully acknowledge the Environmental Protection Agency (EPA) for its support (EPA Project 2006-AQMS-50: Ozone levels, changes and trends over Ireland-an Integrated Analysis). Chris Fairall of NOAA is also gratefully acknowledged for making available the parameterisation used in this study. The authors would also like to thank anonymous reviewers for their comments and reviews that served to significantly improve the quality of the paper.

\section{References}

[1] IPCC, 2001.

[2] IPCC, "Climate Change 2007: the Physical Science Basis. Contribution of Working Group I to the Fourth Assessment Report of the Intergovernmental Panel on Climate Change," 2007.

[3] K. A. Hunter and P. S. Liss, "Organic sea surface films," in Marine Organic Chemistry: Evolution, Composition, Interactions and Chemistry of Organic Matter in Seawater, Elsevier, Amsterdam, The Netherlands, 1981.

[4] US-EPA, "Ozone: good up high, bad nearby," edited by U.S. Environmental Protection Agency, 2003, http://www.epa.gov/oar/oaqps/gooduphigh/.

[5] L. Ganzeveld, D. Helmig, C. W. Fairall, J. Hare, and A. Pozzer, "Atmosphere-ocean exchange: a global modeling study of biogeochemical, atmospheric, and waterside turbulence dependencies," Global Biogeochemical Cycles, vol. 23, Article ID GB4021, 16 pages, 2009. 
[6] L. Ganzeveld and J. Lelieveld, "Dry deposition parameterization in a chemistry general circulation model and its influence on the distribution of reactive trace gases," Journal of Geophysical Research, vol. 100, no. D10, pp. 20999-21012, 1995.

[7] D. A. Hauglustaine, C. Granier, G. P. Brasseur, and G. Megie, "The importance of atmospheric chemistry in the calculation of radiative forcing on the climate system," Journal of Geophysical Research, vol. 99, no. 1, pp. 1173-1186, 1994.

[8] M. Martino, G. P. Mills, J. Woeltjen, and P. S. Liss, "A new source of volatile organoiodine compounds in surface seawater," Geophysical Research Letters, vol. 36, no. 1, Article ID L01609, 5 pages, 2009.

[9] D. I. Reeser, C. George, and D. J. Donaldson, "Photooxidation of halides by chlorophyll at the air-salt water interface," Journal of Physical Chemistry A, vol. 113, no. 30, pp. 8591-8595, 2009.

[10] D. Davis, J. Crawford, S. Liu et al., "Potential impact of iodine on tropospheric levels of ozone and other critical oxidants," Journal of Geophysical Research D, vol. 101, no. 1, pp. 21352147, 1996.

[11] C. D. O’Dowd, J. L. Jimenez, R. Bahreini et al., "Marine aerosol formation from biogenic iodine emissions," Nature, vol. 417, no. 6889 , pp. 632-636, 2002.

[12] A. S. Mahajan, J. M. C. Plane, H. Oetjen, et al., "Measurement and modelling of reactive halogen species over the tropical Atlantic Ocean," Atmospheric Chemistry and Physics Discussions, vol. 9, no. 6, pp. 24281-24316, 2009.

[13] C. W. Fairall, D. Helmig, L. Ganzeveld, and J. Hare, "Waterside turbulence enhancement of ozone deposition to the ocean," Atmospheric Chemistry and Physics, vol. 7, no. 2, pp. 443-451, 2007.

[14] J. H. Seinfeld and S. N. Pandis, Atmospheric Chemistry and Physics, John Wiley \& Sons, New York, NY, USA, 1997.

[15] M. Z. Jacobson, Fundamentals of Atmospheric Modeling, Cambridge University Press, Cambridge, Mass, USA, 2005.

[16] M. L. Wesely and B. B. Hicks, "A review of the current status of knowledge on dry deposition," Atmospheric Environment, vol. 34, no. 12-14, pp. 2261-2282, 2000.

[17] M. W. Gallagher, K. M. Beswick, G. McFiggans, H. Coe, and T. W. Choularton, "Ozone dry deposition velocities for coastal waters," Water, Air and Soil Pollution: Focus, vol. 1, no. 5-6, pp. 233-242, 2001.

[18] M. L. Wesely, "Parameterization of surface resistances to gaseous dry deposition in regional-scale numerical models," Atmospheric Environment, vol. 23, no. 6, pp. 1293-1304, 1989.

[19] D. H. Lenschow, R. Pearson Jr., and B. B. Stankov, "Measurements of ozone vertical flux to ocean and forest," Journal of Geophysical Research, vol. 87, no. 11, pp. 8833-8837, 1982.

[20] W. Chang, B. G. Heikes, and M. Lee, "Ozone deposition to the sea surface: chemical enhancement and wind speed dependence," Atmospheric Environment, vol. 38, no. 7, pp. 1053-1059, 2004.

[21] J. A. Garland, A. W. Etzerman, and S. A. Penkett, "The Mechanism for dry deposition of ozone to seawater surfaces," Journal of Geophysical Research, vol. 85, no. C12, pp. 74887492, 1980.

[22] S. Schwartz, "Factors governing dry deposition of gases to surface water," in Precipitation Scavenging and AtmosphereSurface Exchange, pp. 789-801, Hemisphere Publishing Corporation, Washington, DC, USA, 1992.

[23] D. Clifford, D. J. Donaldson, M. Brigante, B. D'Anna, and C. George, "Reactive uptake of ozone by chlorophyll at aqueous surfaces," Environmental Science and Technology, vol. 42, no. 4, pp. 1138-1143, 2008.
[24] B. Langmann, "Numerical modelling of regional scale transport and photochemistry directly together with meteorological processes," Atmospheric Environment, vol. 34, no. 21, pp. 3585-3598, 2000.

[25] B. Langmann, "REMOTE-Regional Model with Tracer Extension," 2005.

[26] C. W. Fairall, E. F. Bradley, J. S. Godfrey, G. A. Wick, J. B. Edson, and G. S. Young, "Cool-skin and warm-layer effects on sea surface temperature," Journal of Geophysical Research C, vol. 101, no. 1, pp. 1295-1308, 1996.

[27] C. W. Fairall, J. E. Hare, J. B. Edson, and W. McGillis, "Parameterization and micrometeorological measurement of air-sea gas transfer," Boundary-Layer Meteorology, vol. 96, no. 1-2, pp. 63-105, 2000.

[28] J. E. Hare, C. W. Fairall, W. R. McGillis, J. B. Edson, B. Ward, and R. Wanninkhof, "Evaluation of the National Oceanic and Atmospheric Administration/ Coupled-Ocean Atmospheric Response Experiment (NOAA/COARE) air-sea gas transfer parameterization using GasEx data," Journal of Geophysical Research C, vol. 109, no. 8, Article ID C08S11, 11 pages, 2004.

[29] L. Magi, F. Schweitzer, C. Pallares, S. Cherif, P. Mirabel, and C. George, "Investigation of the uptake rate of ozone and methyl hydroperoxide by water surfaces," Journal of Physical Chemistry A, vol. 101, no. 27, pp. 4943-4949, 1997.

[30] P. N. Johnson and R. A. Davis, "Diffusivity of ozone in water," Journal of Chemical and Engineering Data, vol. 41, no. 6, pp. 1485-1487, 1996.

[31] B. Jahne, G. Heinz, and W. Deitrich, "Measurement of the diffusion coefficients of sparingly soluble gases in water," Journal of Geophysical Research, vol. 92, no. C10, pp. 1076710776, 1987.

[32] L. F. Kosak-Channing and G. R. Helz, "Solubility of ozone in aqueous solutions of $0-0.6 \mathrm{M}$ ionic strength at $5-30^{\circ} \mathrm{C}$," Environmental Science and Technology, vol. 17, no. 3, pp. 145149, 1983.

[33] B. Jahne, T. Wais, and M. Barabas, "A new optical bubble measuring device: a simple model for bubble contribution to gas exchange," in Gas Transfer at Water Surfaces, pp. 237-246, D. Reidel, Norwell, Mass, USA, 1984.

[34] L. F. Kosak-Channing and G. R. Helz, "Solubility of ozone in aqueous solutions of $0-0.6 \mathrm{M}$ ionic strength at $5-30^{\circ} \mathrm{C}$," Environmental Science and Technology, vol. 17, no. 3, pp. 145149, 1983.

[35] V. W. Truesdale, A. J. Bale, and E. M. S. Woodward, "The meridional distribution of dissolved iodine in near-surface waters of the Atlantic Ocean," Progress in Oceanography, vol. 45, no. 3-4, pp. 387-400, 2000.

[36] M. L. A. M. Campos, R. Sanders, and T. Jickells, "The dissolved iodate and iodide distribution in the South Atlantic from the Weddell Sea to Brazil," Marine Chemistry, vol. 65, no. 3-4, pp. 167-175, 1999.

[37] MODIS, "Oceancolor Web," http://oceancolor.gsfc.nasa.gov/.

[38] G. McFiggans, J. M.C. Plane, B. J. Allan, L. J. Carpenter, H. Coe, and C. O'Dowd, "A modeling study of iodine chemistry in the marine boundary layer," Journal of Geophysical Research D, vol. 105, no. D11, pp. 14371-14385, 2000.

[39] O. P. Tripathi, S. G. Jennings, C. D. O’Dowd, et al., "Statistical Analysis of Eight Surface Ozone Measurement Series for various sites in Ireland," Journal of Geophysical Reseach. In press.

[40] G. McFiggans, H. Coe, R. Burgess et al., "Direct evidence for coastal iodine particles from Laminaria macroalgae-linkage to emissions of molecular iodine," Atmospheric Chemistry and Physics, vol. 4, no. 3, pp. 701-713, 2004. 
[41] C. E. Jones, K. E. Hornsby, R. Sommariva, et al., "Quantifying the contribution of marine organic gases to atmospheric iodine," Geophys. Res. Lett, in press.

[42] K. A. Rahn, R. D. Borys, and R. A. Duce, "Tropospheric halogen gases: inorganic and organic components," Science, vol. 192, no. 4239, pp. 549-550, 1976.

[43] S. Yoshida and Y. Muramatsu, "Determination of organic, inorganic and particulate iodine in the coastal atmosphere of Japan," Journal of Radioanalytical and Nuclear Chemistry, vol. 196, no. 2, pp. 295-302, 1995.

[44] R. Vogt, R. Sander, R. Von Glasow, and P. J. Crutzen, "Iodine chemistry and its role in halogen activation and ozone loss in the marine boundary layer: a model study," Journal of Atmospheric Chemistry, vol. 32, no. 3, pp. 375-395, 1999.

[45] K. A. Read, A. S. Mahajan, L. J. Carpenter et al., "Extensive halogen-mediated ozone destruction over the tropical Atlantic Ocean," Nature, vol. 453, no. 7199, pp. 1232-1235, 2008. 

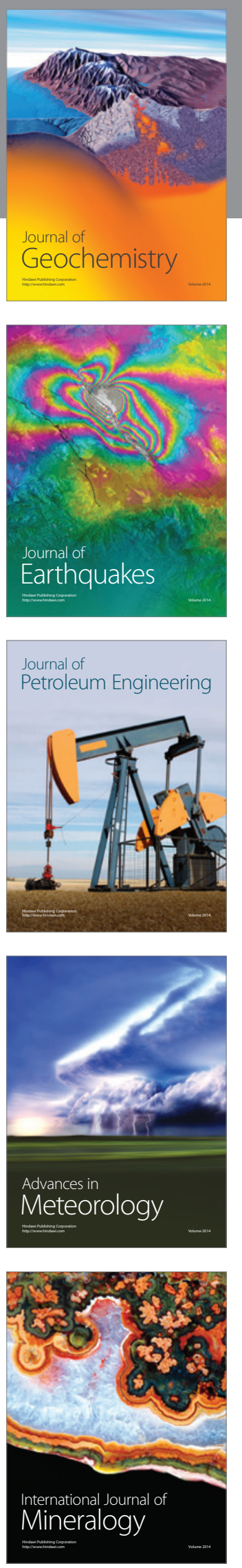
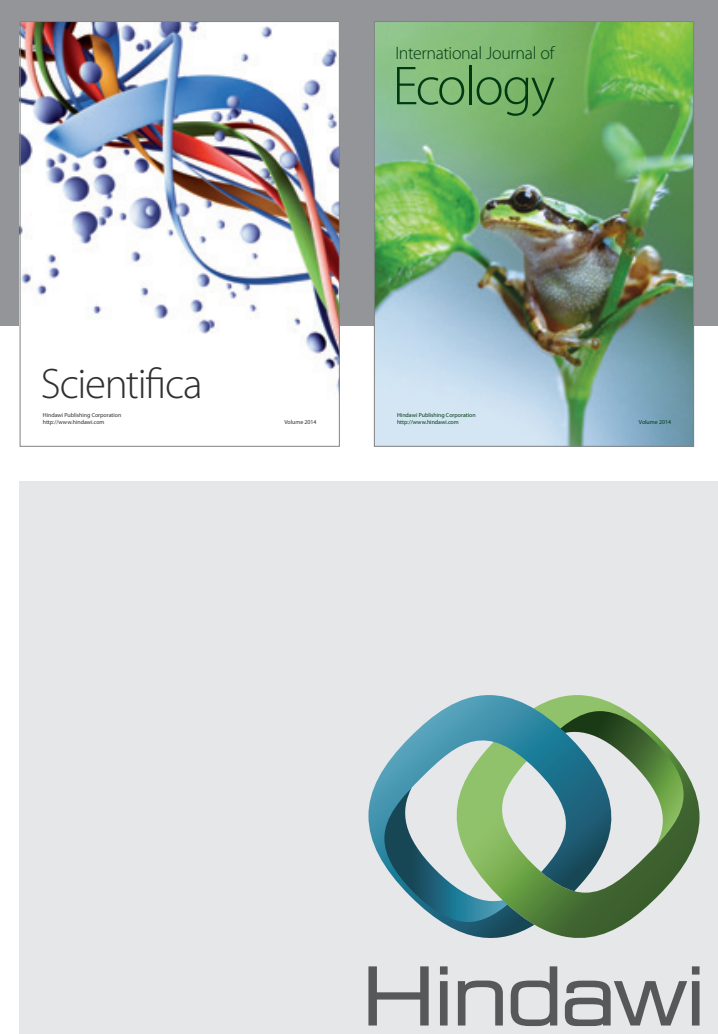

Submit your manuscripts at http://www.hindawi.com
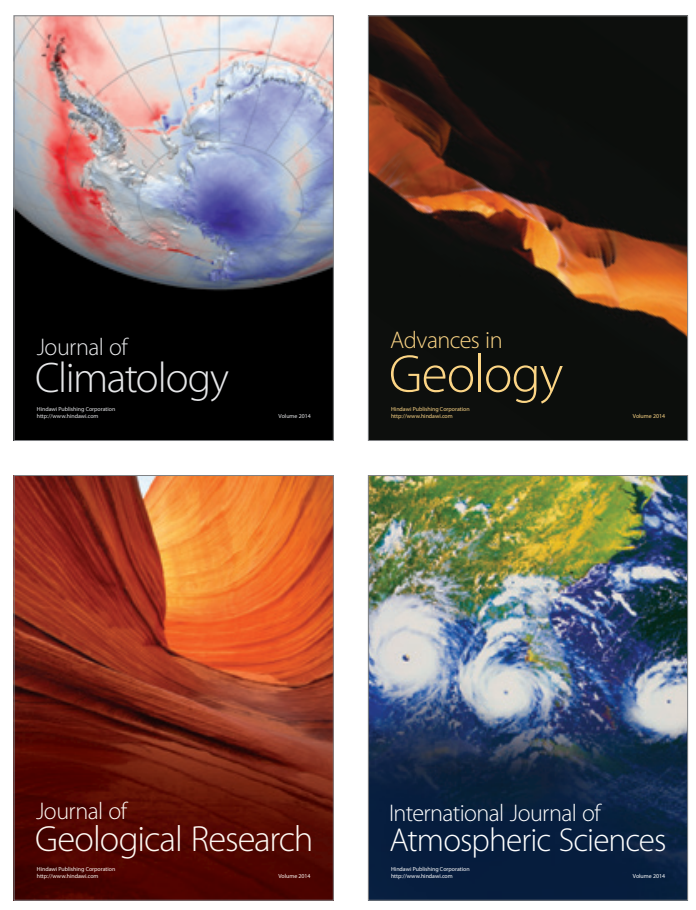
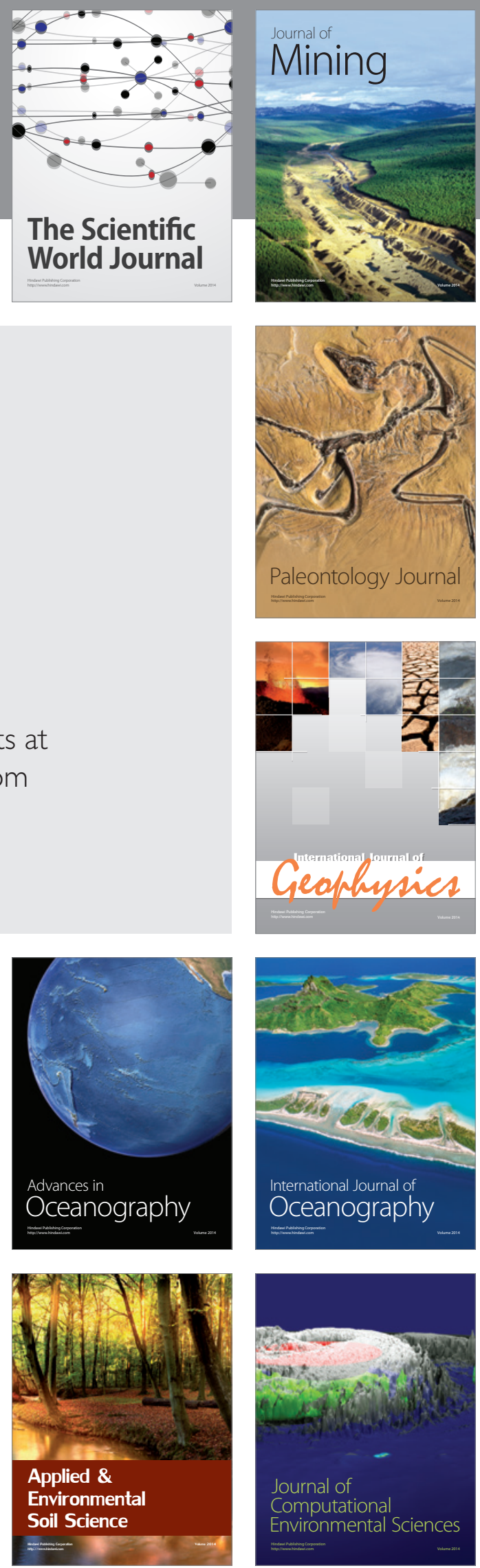